
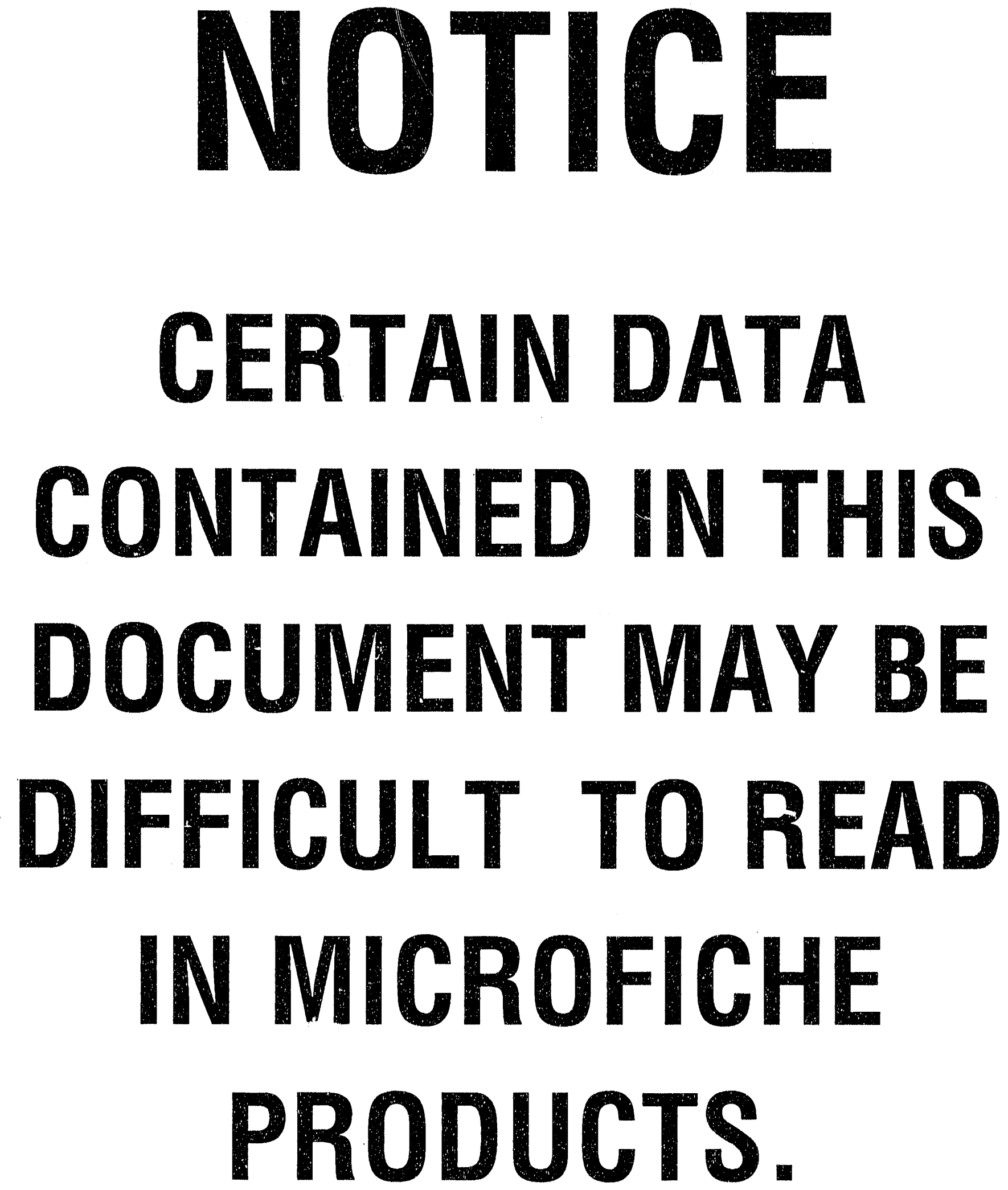


\section{ENHANCING THE USE OF COALS BY GAS REBURNING-SORBENT INJECTION}

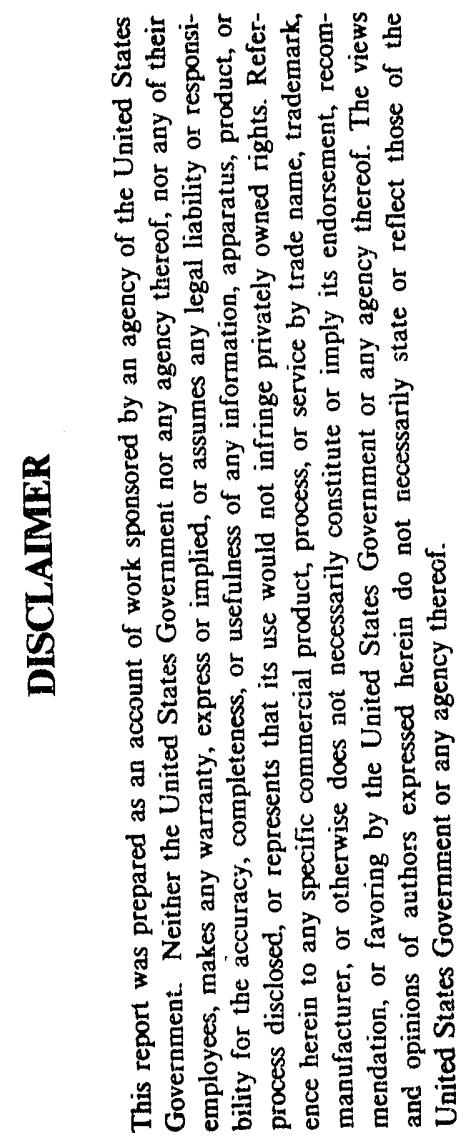

Environmental Monitoring Report

Quarterly Report No. 6

For the Period

October 1-December 31, 1991

Prepared for

U.S. Department of Energy

Gas Research Institute

State of Illinois Department of

Energy and Natural Resources

FC22.87PC 74796

Prepared by

Energy and Environmental Research Corporation

18 Mason

Irvine, California 92718

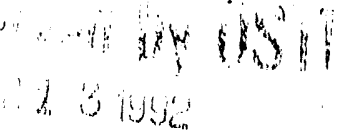


TABLE OF CONTENTS

Page

$1.0 \quad$ INTRODUCTION $\ldots \ldots \ldots \ldots \ldots \ldots \ldots \ldots \ldots \ldots \ldots$

2.0 ENVIRONMENTAL MONITORING $\ldots \ldots \ldots \ldots \ldots \ldots \ldots \ldots \ldots$

2.1 Compliance Monitoring $\ldots \ldots \ldots \ldots \ldots \ldots \ldots \ldots \ldots \ldots$

2.1 .1 Hennepin $\ldots \ldots \ldots \ldots \ldots \ldots \ldots \ldots \ldots \ldots \ldots \ldots$

2.1 .2 Lakeside $\ldots \ldots \ldots \ldots \ldots \ldots \ldots \ldots \ldots \ldots \ldots \ldots \ldots$

2.2 Supplemental Monitoring $\ldots \ldots \ldots \ldots \ldots \ldots \ldots \ldots \ldots \ldots \ldots$

2.2 .1 Hennepin $\ldots \ldots \ldots \ldots \ldots \ldots \ldots \ldots \ldots \ldots \ldots \ldots \ldots$

$2.2 .2 \quad$ Lakeside $\ldots \ldots \ldots \ldots \ldots \ldots \ldots \ldots \ldots \ldots \ldots \ldots \ldots, 12$

3.0 DATA DISCUSSION ....................... 15

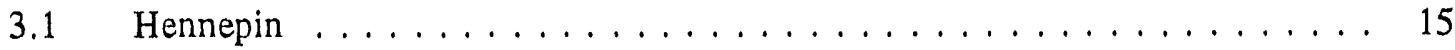

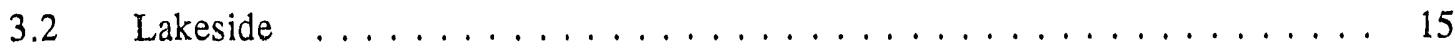

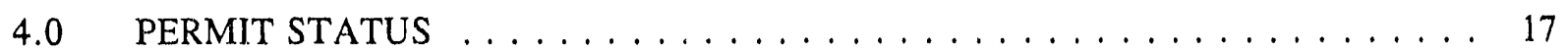

$4.1 \quad$ Hennepin $\ldots \ldots \ldots \ldots \ldots \ldots \ldots \ldots \ldots \ldots \ldots \ldots \ldots \ldots$

4.2 Lakeside $\ldots \ldots \ldots \ldots \ldots \ldots \ldots \ldots \ldots \ldots \ldots \ldots \ldots \ldots$

5.0 MODIFICATIONS TO MONITORING PLAN $\ldots \ldots \ldots \ldots \ldots \ldots$

$5.1 \quad$ Hennepin $\ldots \ldots \ldots \ldots \ldots \ldots \ldots \ldots \ldots \ldots \ldots \ldots \ldots \ldots$

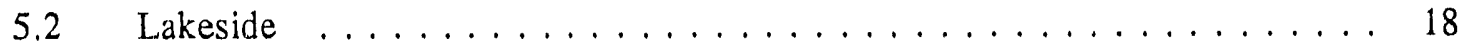




\subsection{INTRODUCTION}

Clean Coal Technology implies the use of coal in an environmentally acceptable manner. Coal combustion results in the emission of two types of acid rain precursors: oxides of sulfur $\left(\mathrm{SO}_{x}\right)$ and oxides of nitrogen $\left(\mathrm{NO}_{x}\right)$. This Clean Coal Technology project will demonstrate a combination of two developed technologies to reduce both $\mathrm{NO}_{\mathrm{x}}$ and $\mathrm{SO}_{\mathrm{x}}$ emissions: gas reburning and calcium based dry sorbent injection. The demonstrations will be conducted on two pre-NSPS utility boilers representative of the U.S. boilers which contribute significantly to the inventory of acid rain precursor emissions: tangentially and cyclone fired units. Because of cost growth and lack of available funding, no further work has been done after Phase I at site B; the wall fired unit.

Gas reburning is a combustion modification technique that consists of firing $80-85$ percent of the fuel (corresponding to the total heat release) in the lower furnace. Reduction of $\mathrm{NO}_{x}$ to molecular nitrogen $\left(\mathrm{N}_{2}\right)$ is accomplished via the downstream injection of the remaining fuel requirement in the form of natural gas (which also reduces the total $\mathrm{SO}_{\mathrm{x}}$ emissions). In a third stage, burnout air is injected at lower temperatures in the upper furnace to complete the combustion process without generating significant additional $\mathrm{NO}_{x}$.

Dry sorbent injection consists of injecting calcium based sorbents (such as limestone dolomite, or hydrated lime) into the combustion products. For sulfation of the sorbent to $\mathrm{CaSO}_{4}$, an injection temperature of about $1230^{\circ} \mathrm{C}$ is optimum, but calcium-sulfur reactions can also take place at lower temperatures. Thus, the sorbent may be injected at different 'ocations, such as with the burnout air, at the exit from the superheater, or into the ducting downstream of the air heater with $\mathrm{H}_{2} \mathrm{O}$ added for humidification. The calcium sulfate or sulfite products are collected together with unreacted sorbent fly ash by the electrostatic precipitator. The specific goal of this project is to demonstrate $\mathrm{NO}_{\mathrm{x}}$ and $\mathrm{SO}_{\mathrm{x}}$ emission reductions of 60 percent and 50 percent, respectively, on two coal fired utility boilers having the design characteristics mentioned above.

At the inception of the project, Host Site Agreements were signed by EER and three utility companies in the State of Illinois: Site A, Illinois Power Company [Hennepin Unit 1, $71 \mathrm{MW}$ (net) tangentially fired boiler in Hennepin]; Site B, Central Illinois Light Company [Edwards Unit 1, 117 MW (net) front wall fired boiler in Bartonville; and Site C, City Water Light and Power [Lakeside Unit 7, $33 \mathrm{MW}$ (net) cyclone fired boiler in Springfield]. 
Funding for this project is provided by the U.S. Department of Energy (DOE), the Gas Research Institute (GRI), and the Illinois Department of Energy and Natural Resources (ENR)--the other funding participants. GRI and ENR are responsible for funding approximately one-third and one-sixth, respectively, of the total project costs.

To achieve its objectives, the project is conducted in the following three phases at each site:

Phase I: Design and Permitting

Phase II: Construction and Startup

Phase III: Operation, Data Collection, Reporting, and Disposition

Phase I work has been completed for all three sites. Because of cost growth and lack of available funding, no further work has been done after Phase I at Site B; the wall fired unit. At Site A, Phase II has been completed and Phase III long-term tests are currently being initiated. Site C is currently in Phase II of the program.

In accordance with the cooperative agreement, EER has prepared an Environmental Monitoring Plan to verify that no adverse environmental impacts would be associated with the project, to determine if projected emission control levels are being met, and to maintain a data base for future development of GR-SI technology. Tables 1 through 4 show the envirommental monitoring to be conducted at Sites A and C, (Hennepin and Lakeside) during Phases I, II and III of the project.

The following section provides a description of the monitoring which has been conducted during the previous quarter at the host sites. A discussion of the monitoring results is presented in Section 3. Section 4 provides a status report of permits obtained for the project at each facility, and Section 5 discusses any proposed changes in the original monitoring plan based on available information. 


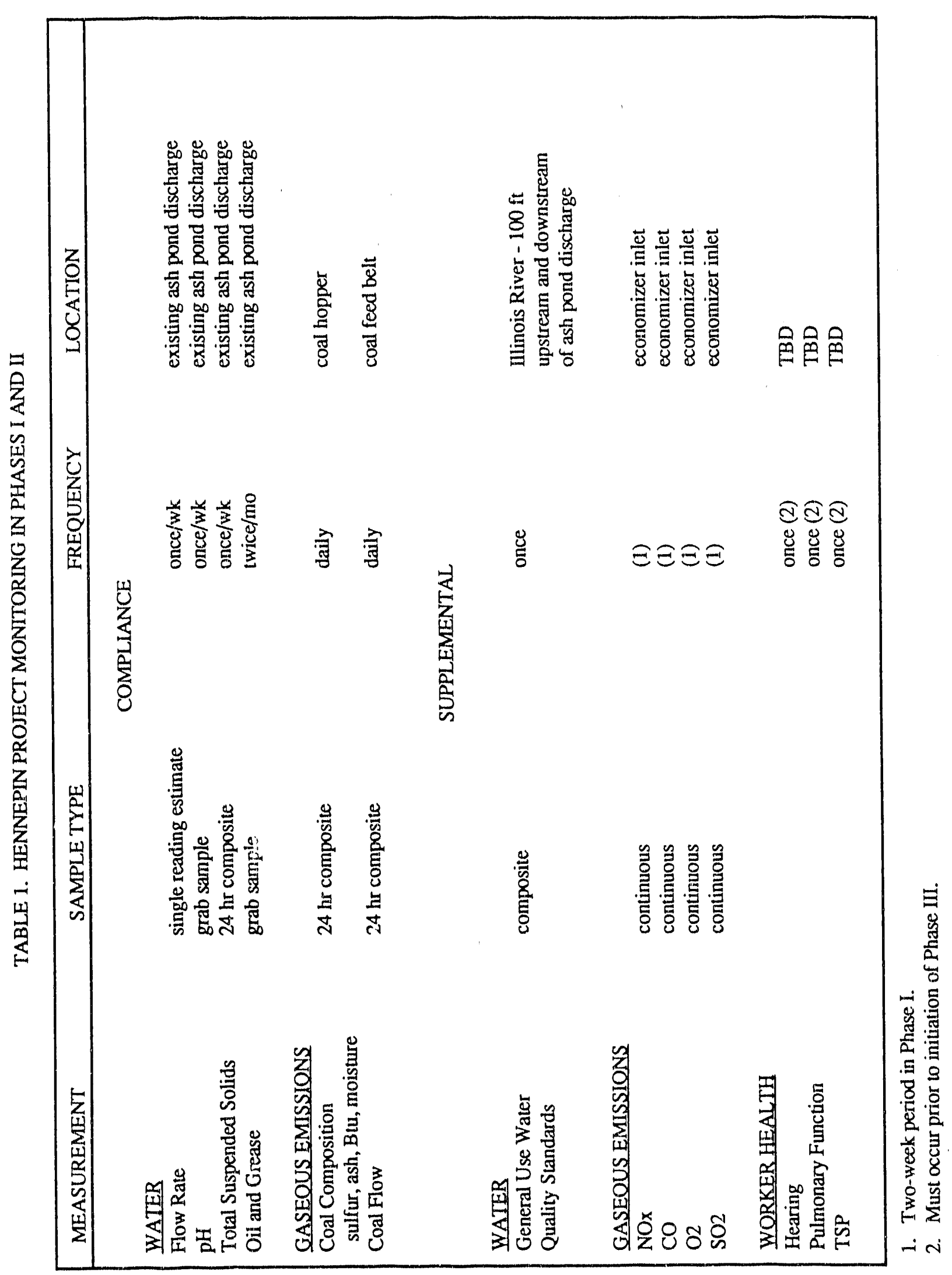




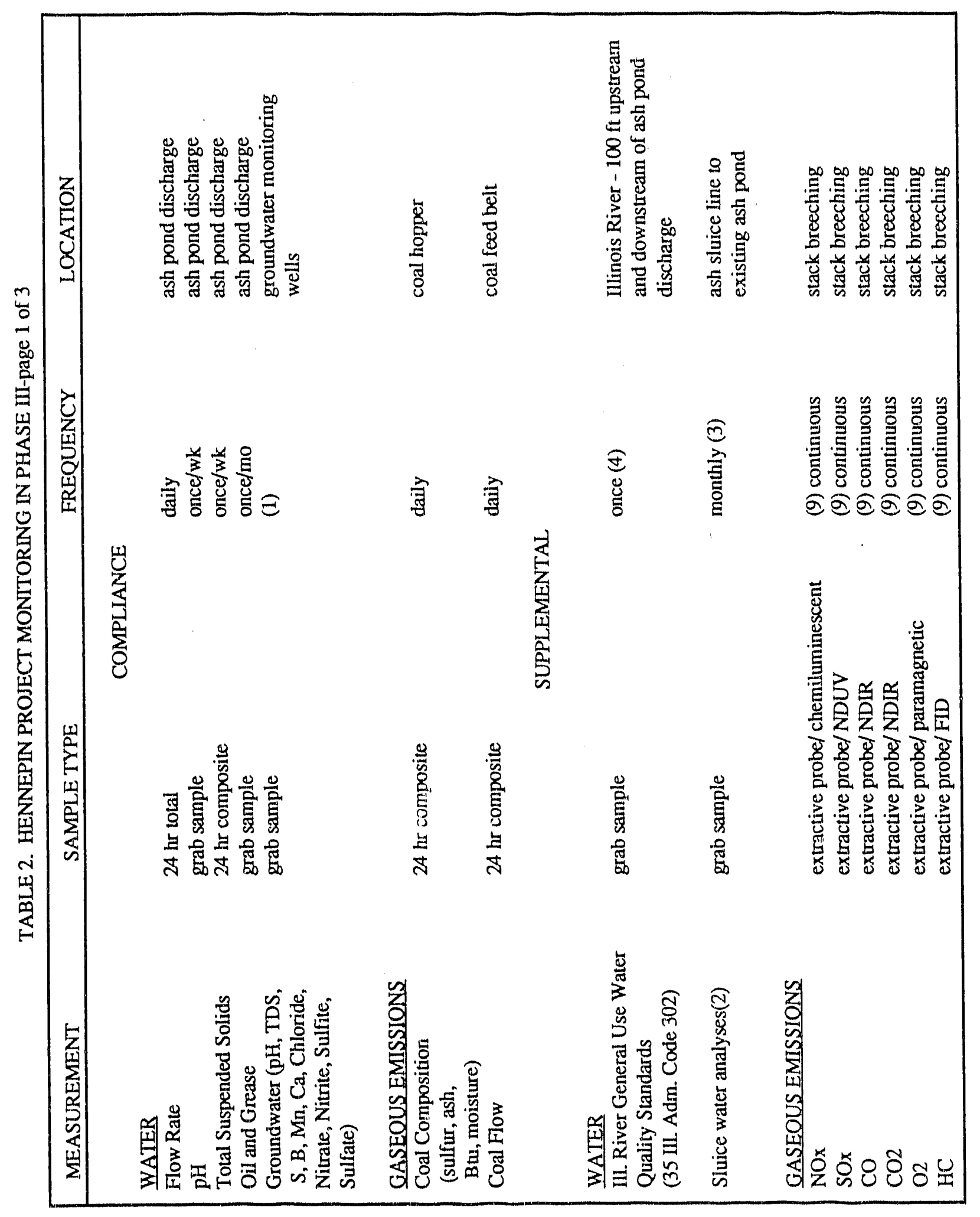




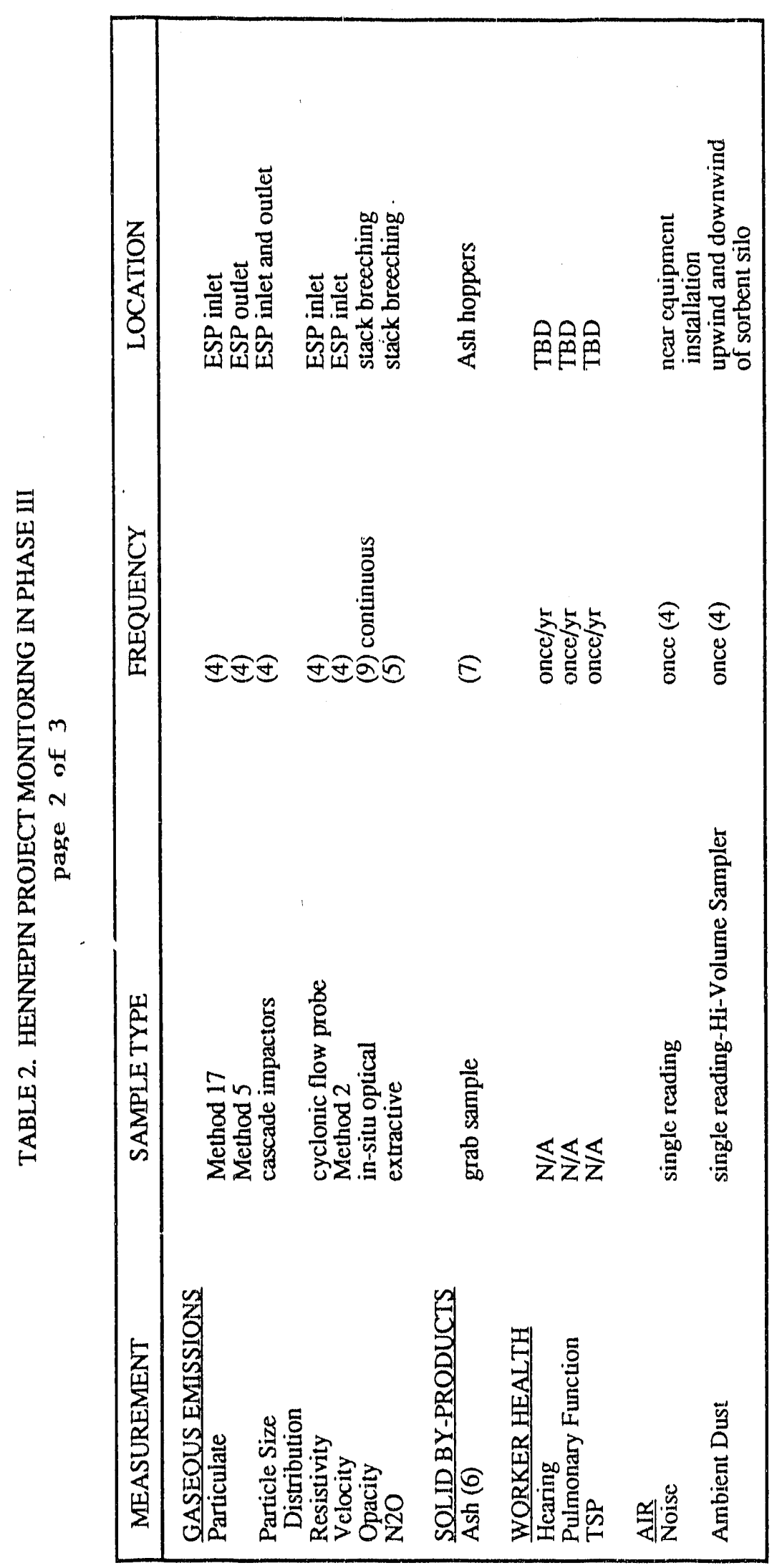




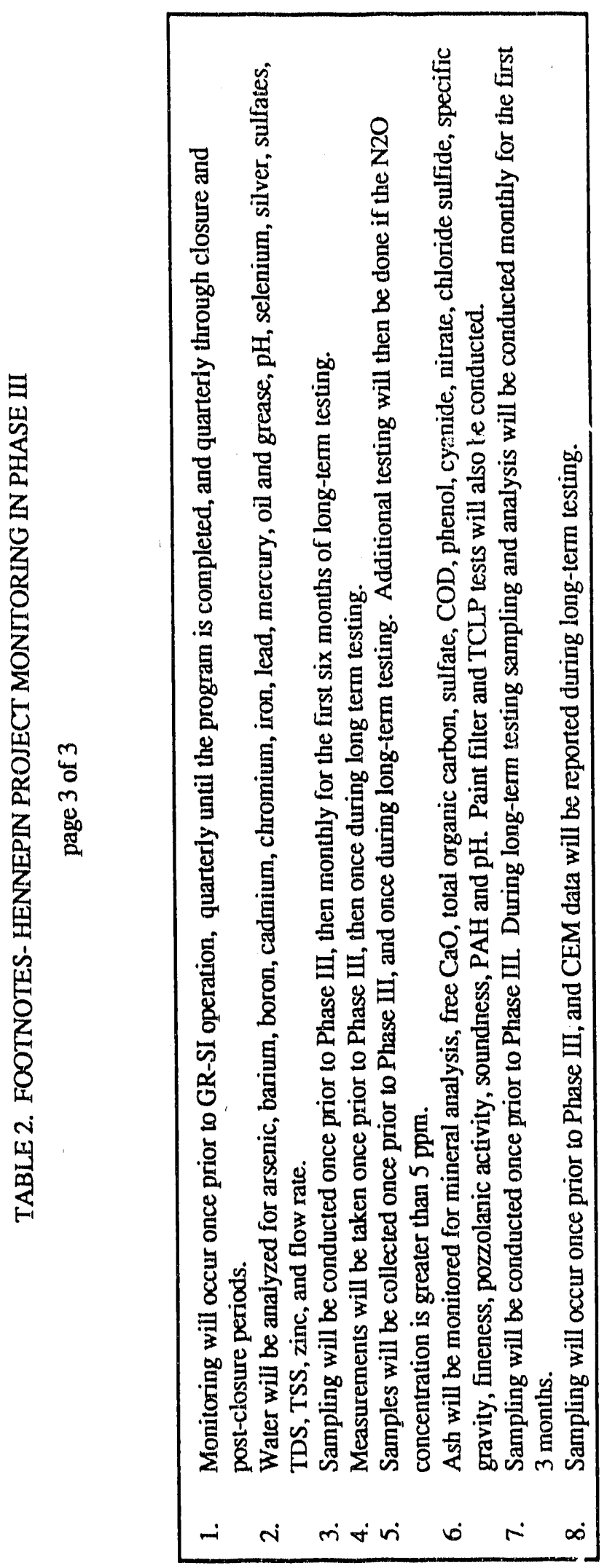




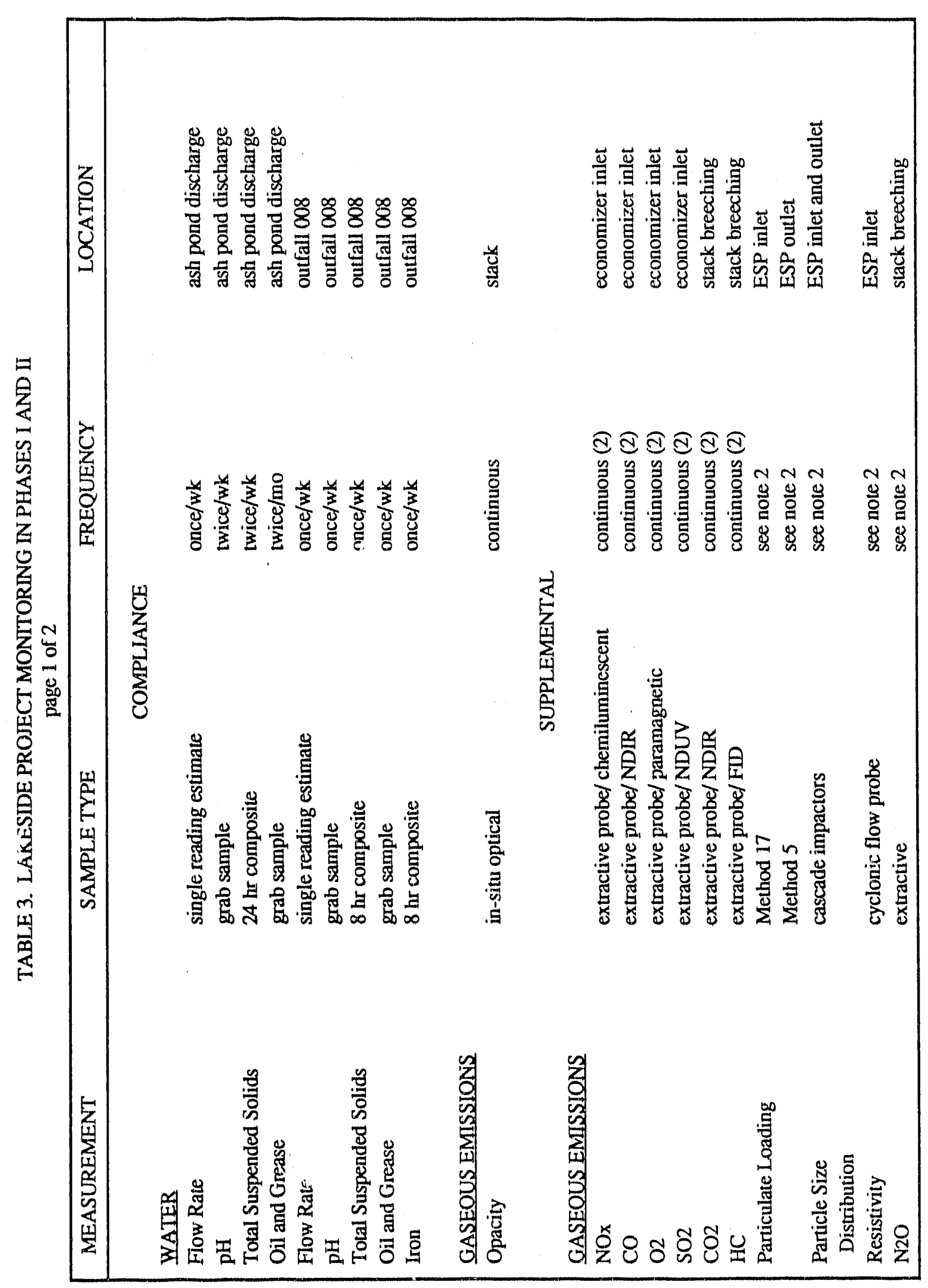




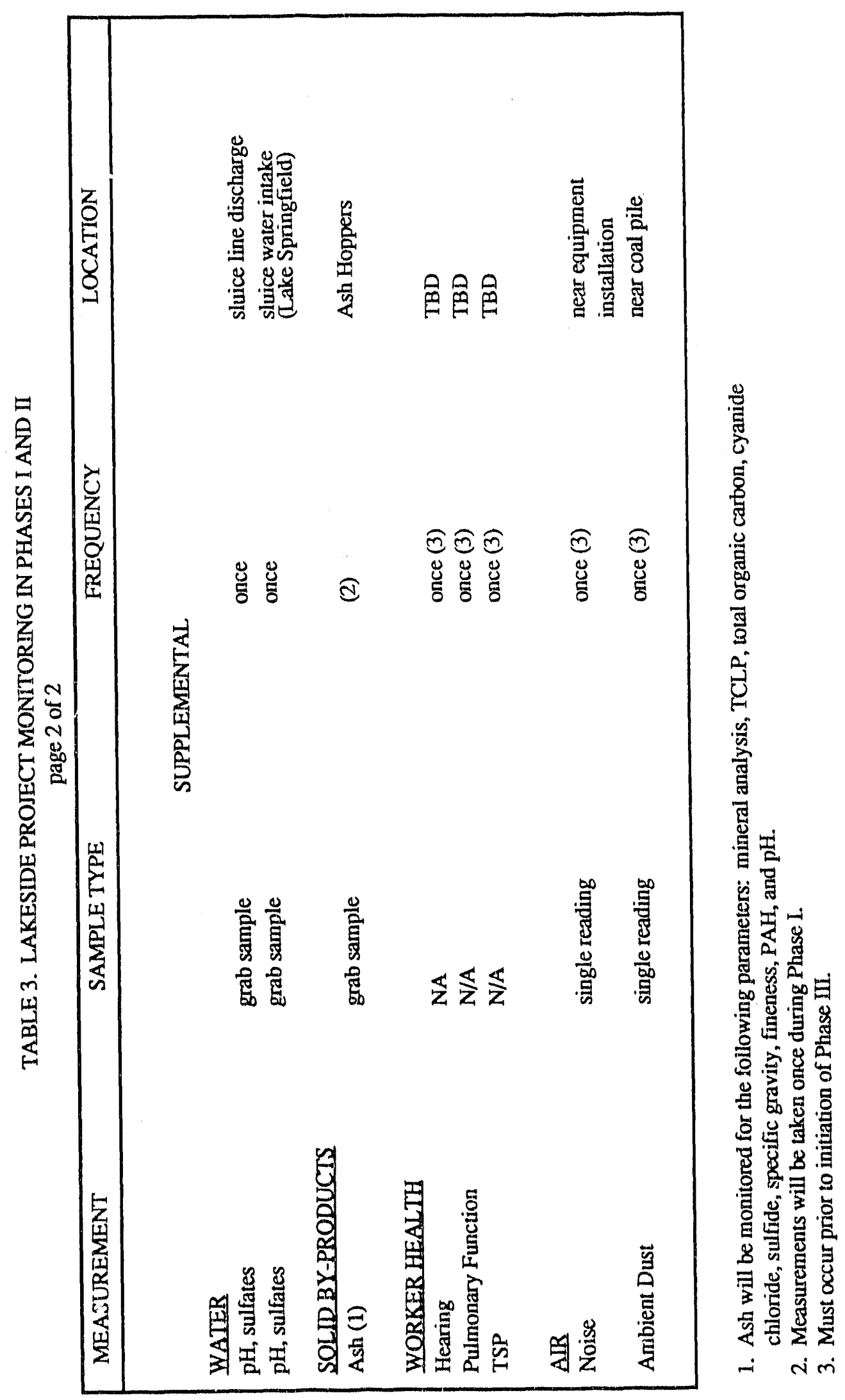




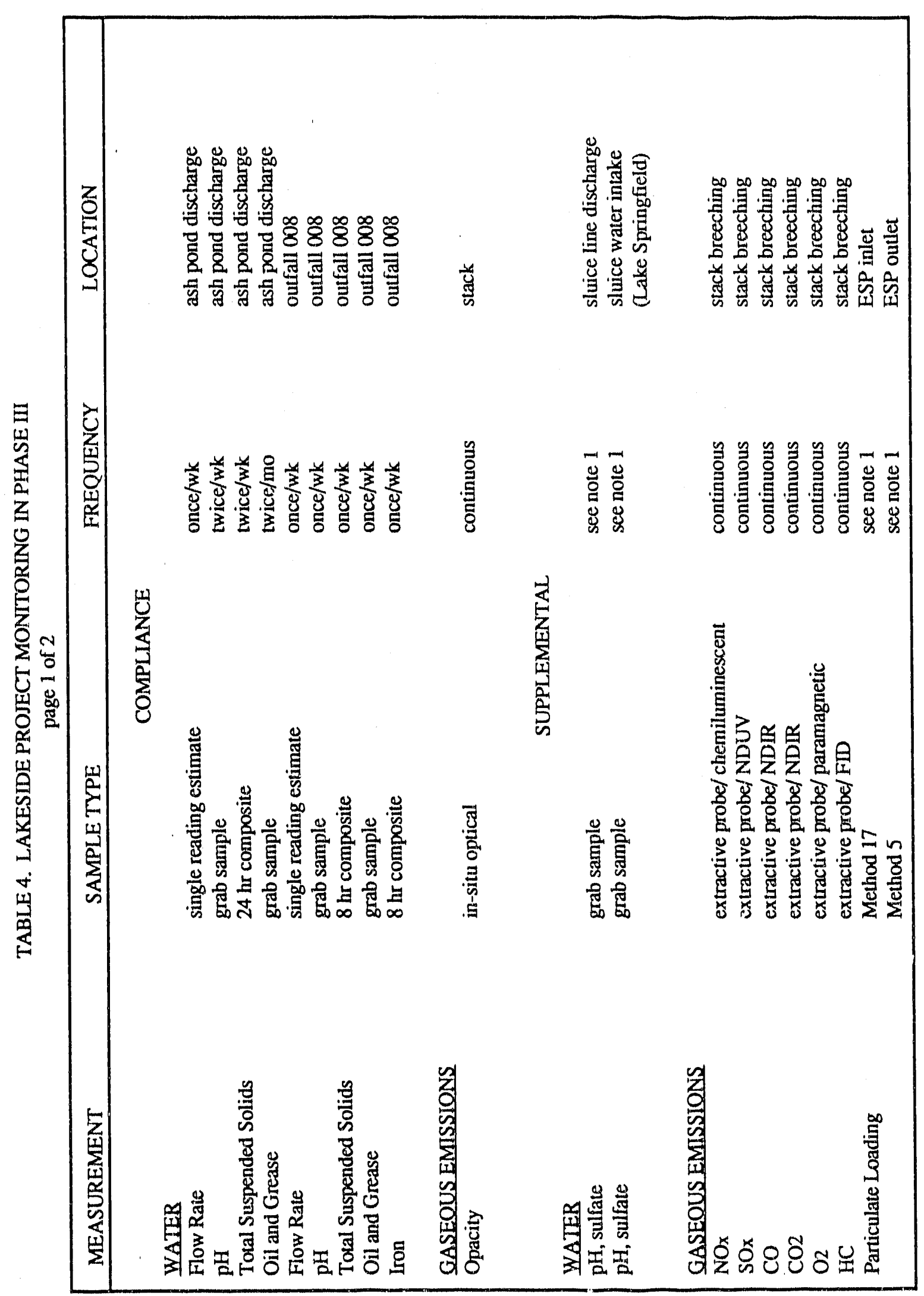




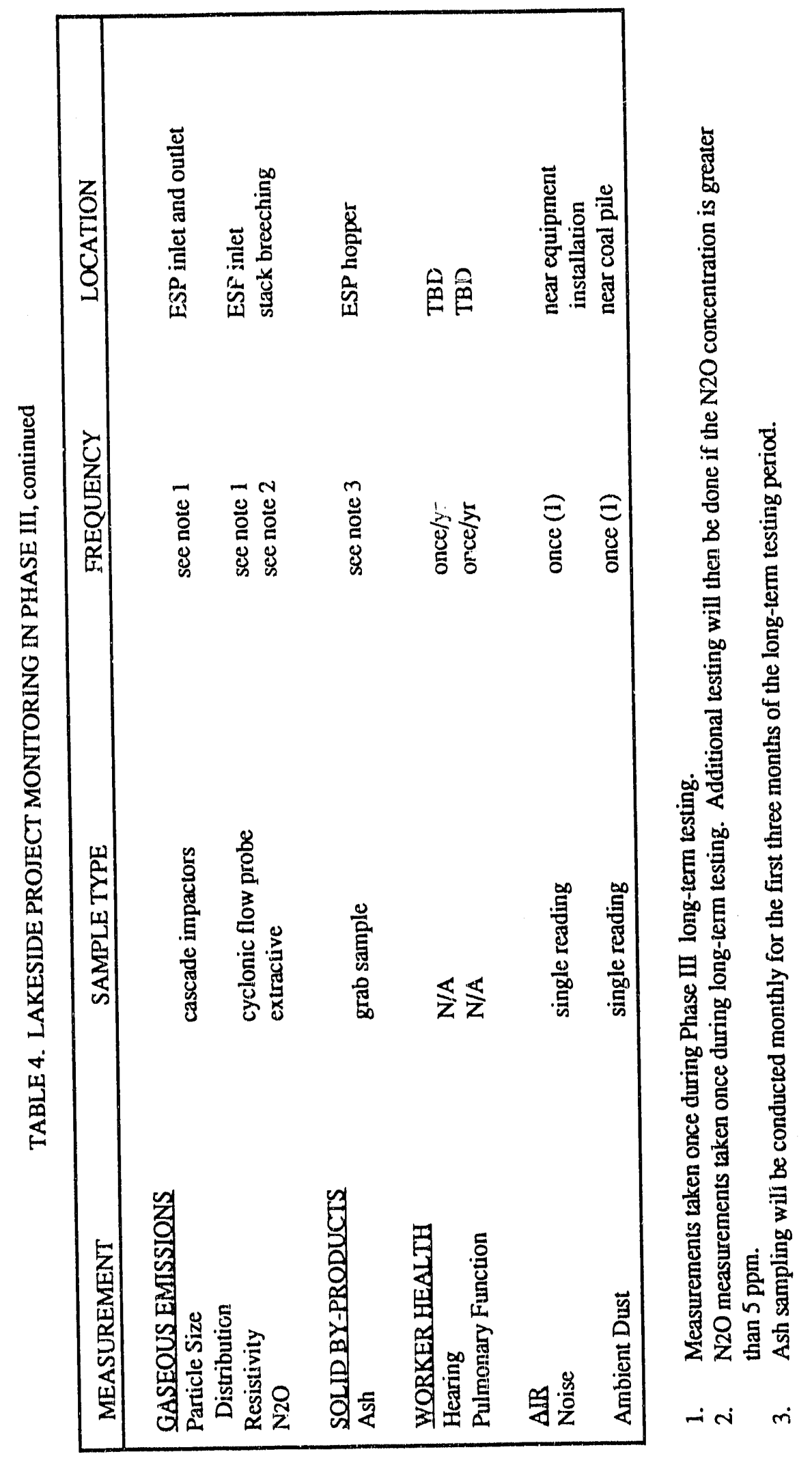




\subsection{ENVIRONMENTAL MONITORING}

Both compliance and supplemental monitoring was conducted at the Hennepin and Lakeside sites during the previous quarter. The monitoring results from Hennepin and Lakeside are presented in the following sections.

\section{Compliance Monitoring}

Compliance monitoring is that monitoring required by Federai, State or local authorities.

\subsubsection{Hennepin}

The compliance monitoring conducted at Hennepin during the quarter which directly influences this project includes NPDES permit monitoring and coal quality seports. Illinois Power submits NPDES Discharge Monitoring Reports to the Illinois EPA, on a monthly basis. Coal quality reports are submitted to Illinois EPA on a quarterly basis. Copies of the discharge monitoring, and coal quality reports for October, November, and December are included in Appendix A of this report.

All personnel engaged in manual sampling or subject to frequent exposure to the process areas have had physical examinations which included pulmonary function testing.

\subsubsection{Lakeside}

The compliance monitoring conducted at Lakeside during the quarter which directly influences this project includes NPDES permit monitoring and gaseous emissions opacity reports. Copies of the reports for October, November, and December are included in Appendix B of this report.

\subsection{Supplemental Monitoring}

\subsubsection{Hennepin}

The supplemental monitoring reported during this quatter included baseline resistivity measurements and a baseline opacity reading. Illinois Power submitted baseline opacity readings for 
the month of May that ranged from 5 to $21.1 \%$ opacity. The average baseline opacity reading was 2.65 percent.

Gaseous Emissions

Hydrocarbon emissions were monitored under baseline condition at low, mid and high loads. Results corrected to $3 \% \mathrm{O}_{2}$ are shown below:

\begin{tabular}{ccc}
\multicolumn{3}{c}{ Hydrocarbon Concentration ppmv $\left(@ 3 \% \mathrm{O}_{2}\right)$} \\
$\underline{\text { Load }}$ & $\underline{\text { Range }}$ & $\underline{\text { Average }}$ \\
Low $(-45 \mathrm{MW})$ & $1-61$ & 24 \\
Mid $(50-65 \mathrm{MW})$ & $0-4$ & 2.6 \\
High $(65-75 \mathrm{MW})$ & $3-31$ & 10
\end{tabular}

Resistivity

The baseline resistivity measurements are listed below by both spark method and voltage current method reported in ohm-cm.

\begin{tabular}{|c|c|c|c|}
\hline \multicolumn{2}{|c|}{ Temperature (F) } & \multicolumn{2}{|c|}{ Resistivity (ohm- $\mathrm{cm}$ ) } \\
\hline & & Spark Method & V-I Method \\
\hline $1-$ & 316 & (-)- & $7.6 \times 10^{10}$ \\
\hline $2-$ & 331 & $6.9 \times 10^{9}$ & $2.5 \times 10^{10}$ \\
\hline $3-$ & 331 & $2.7 \times 10^{9}$ & $3.6 \times 10^{10}$ \\
\hline 4- & 331 & $1.2 \times 10^{10}$ & $5.0 \times 10^{10}$ \\
\hline $5-$ & 331 & $1.1 \times 10^{10}$ & $3.8 \times 10^{10}$ \\
\hline $6-$ & 333 & $2.6 \times 10^{10}$ & $3.7 \times 10^{10}$ \\
\hline
\end{tabular}

\subsubsection{Lakeside}

The supplemental monitoring reported during this quarter included baseline emissions data for $\mathrm{NO}_{x}, \mathrm{SO}_{2}, \mathrm{CO}, \mathrm{CO}_{2}, \mathrm{HC}$. Baseline opacity data is also reported. 


\section{Gaseous Emissions}

The baseline opacity readings for Lakeside are $<30 \%$ as reported by City Water Light and Power. The average baseline gaseous emissions data is reported below in corrected form by load and level of excess oxygen. The various loads consisted of $33 \mathrm{MW}, 25 \mathrm{MW}$, and 19.5 MW. All loads were run at normal and low excess oxygen levels. The emissions data is included in Appendix $\mathrm{C}$ of this report.

At 33 MW-Normal $\mathrm{O}_{2}$ levels

$\begin{array}{lllll}\mathrm{CO}_{2} \mathrm{c} & \mathrm{COc} & \mathrm{NO}_{\mathrm{x}} \mathrm{c} & \mathrm{SO}_{2} \mathrm{c} & \mathrm{HCc} \\ \text { Percent } & \text { ppmv } & \text { npmv } & \text { nnmv } & \text { npmv } \\ 15.55 & 7.53 & 699.71 & 2794.23 & 17.57\end{array}$

At $33 \mathrm{MW}$-Low $\mathrm{O}_{2}$ levels

$\begin{array}{lllll}\mathrm{CO}_{2} \mathrm{c} & \mathrm{COc} & \mathrm{NO}_{x} \mathrm{c} & \mathrm{SO}_{2} \mathrm{c} & \mathrm{HCc} \\ \text { Percent } & \text { ppmv } & \text { ppmv } & \text { ppmv } & \text { ppmv } \\ 15.58 & 79.31 & 652.42 & 2855.65 & 9.98\end{array}$

At $25 \mathrm{MW}$ - Normal $\mathrm{O}_{2}$ levels

$\begin{array}{lllll}\mathrm{CO}_{2} \mathrm{c} & \mathrm{COc} & \mathrm{NO}_{\mathrm{x}} \mathrm{c} & \mathrm{SO}_{2} \mathrm{c} & \mathrm{HCc} \\ \text { Percent } & \text { npmv } & \text { ppmv } & \text { ppmv } & \text { ppmv } \\ 15.57 & 6.33 & 646.27 & 2820.04 & 8.58\end{array}$

At $25 \mathrm{MW}$-Low $\mathrm{O}_{2}$ levels

$\begin{array}{lllll}\mathrm{CO}_{2} \mathrm{c} & \mathrm{COc} & \mathrm{NO}_{\mathrm{x}} \mathrm{c} & \mathrm{SO}_{2} \mathrm{c} & \mathrm{HCc} \\ \text { Percent } & \text { npmv } & \text { npmv } & \text { npmv } & \text { npmv } \\ 15.36 & 39.89 & 673.22 & 2933.28 & 15.12\end{array}$

At 19.5 MW-Normal $\mathrm{O}_{2}$ levels

$\begin{array}{lllll}\mathrm{CO}_{2} \mathrm{c} & \mathrm{COc} & \mathrm{NO}_{x} \mathrm{c} & \mathrm{SO}_{2} \mathrm{c} & \mathrm{HCc} \\ \text { Percent } & \text { npmv } & \text { npmv } & \text { npmv } & \text { npniv } \\ 15.54 & 4.69 & 647.48 & 2831.32 & 14.33\end{array}$


At 19.5 MW-Low $\mathrm{O}_{2}$ levels

\begin{tabular}{lllll}
$\mathrm{CO}_{2} \mathrm{c}$ & $\mathrm{COc}$ & $\mathrm{NO}_{\mathrm{x}} \mathrm{c}$ & $\mathrm{SO}_{2} \mathrm{c}$ & $\mathrm{HCc}$ \\
Percent & nmv & npmv & npmv & nnmv \\
\hline 15.44 & 29.8 & 618.11 & 2844.80 & 9.75
\end{tabular}




\subsection{Hennepin}

The discharge monitoring reports for October through December indicated that no effluents were discharged from the ash pond to the Illinois River. The gaseous emissions for the coal composition did not exceed the regulatory emission rate 17,050 lbs. of $\mathrm{SO}_{2}$ per hour. The average lbs. of $\mathrm{SO}_{2}$ per MBTU for this quarter was 5.24.

The baseline resistivity measurements were taken by APCO Services in July 1991. The resistivity data indicates that there was good agreement between all runs for the V-I measurements and fair agreement between the spark and V-I measurements. It is not uncommon to see differences in the spark and V-I data when testing higher resistivity ashes. APCO Services indicated that the V-I data is more representative of the true resistivity.

The baseline opacity measurements for Hennepin indicate that the opacity levels are well below the Illinois State opacity limit of $30 \%$. This opacity reading is a combined reading for the Hennepin station, and does not accurately represent the opacity levels from only Unit \#1. As a result, EER will report particulate measurements for Hennepin Unit \#1 in place of opacity readings in the future.

\section{$3.2 \quad \underline{\text { Lakeside }}$}

The discharge monitoring reports for the ash pond outfall structure and the coal pile runoff during the months of October through December indicate that the ash pond outfall had $\mathrm{Ph}$ exceedances for the months October through December and one Boron exceedance for the month of December. The coal pile runoff did not produce a discharge stream during this quarter.

The gaseous emissions opacity reports indicate the opacity limit of $30 \%$ was exceeded during the month of October due to an unknown cause, during the month of November due to the startup and shutdown of the boilers, and during the month of December due to start up of the boilers and malfunctioning board which was replaced. 
The baseline gaseous emissions data indicate that the readings are typical of a coal-fired utility boller operating under varying loads. The variation in $\mathrm{CO}$ is representative of the change in excess air levels.

The baseline opacity reading taken in July 1991 indicated that the opacity limit of $30 \%$ was exceeded only during startup and shutdown of the boilers and when maintenance to the power supply was necessary. 


\subsection{PERMIT STATUS}

Permits have been obtained for construction and operation of the GR-SI system at Hennepin. At Lakeside, construction is in progress, and operating permits have not been obtained yet. The following sections describe the permits obtained at each host site.

\section{$4.1 \quad$ Hennepin}

IP applied for a construction permit for the GR-SI project at Hennepin on July 7, 1989, and Illinois Environmental Protection Agency granted that permit on October 18, 1989. A modification to the construction permit for operation of the GR-SI demonstration for a period of 270 days was requested. This permit was granted June 21, 1990. A permit also was required to install the $\mathrm{Ph}$ adjustment system for the GR-SI ash transport water to the existing ash pond. This permit was granted on July 25, 1990. Negotiations are currently underway between Illinois Power, the Illinois EPA, and the U.S. EPA regarding the reissuing of the Hennepin NPDES permit. This permit should be reissued during the next quarter.

\subsection{Lakeside}

On January 8, 1990, CWLP submitted a PSD permit application for the GR-SI demonstration at Lakeside Unit 7. On July 5, 1990, CWLP granted the Illinois Environmental Protection Agency a waiver from its statutory deadline to review the permit application (180 days) for a period of 120 days. Permit approval was received November 16,1990. EER is in the process of applying for a Special Waste Permit through the Christian County Landfill for the future disposal of the Lakeside fly ash waste stream. 


\subsection{Hennepin}

The recommended modifications to the proposed monitoring plan as listed in Tables 2 are as follows: Under the supplemental water measurement category, the frequency of monitoring the Illinnis River has been changed to reflect monitoring once prior to Phase III testing, and once during longterm testing; Under the gaseous emissions category the opacity parameter has been deleted and replaced with p'rticulate data because the combined stack opacity readings at Hennepin do not accurately represent only Unit \#1 opacity readings; Also under the gaseous emissions category the velocity parameter has been deleted due to the combined stack velocity readings. The combined stack velocity readings do not provide accurate data for conducting ambient air models for Unit \#1.

The recommended modifications to the fontnotes in Table 2 are listed below.

Footnote \#1- Monitoring will occur once prior to GR-SI operation, quarterly until the program is completed, and quarterly through closure and post-closure periods.

Footnote \#3 - Sampling will be conducted once prior to Phase III, then monthly for the first six months of long-term testing.

Footnote \#5 - Samples will be collected once prior to Phase III, and once during long-term testing. Additional testing will conducted if the $\mathrm{N}_{2} \mathrm{O}$ concentration exceeds 5 ppm.

Footnote \#7 - Sampling will be conducted once prior to Phase III. During long-term testing, sampling will be conducted monthly for the first three months.

Footnote \#8 -Sampling will occur once prior to Phase III, and CEM data will be reported during long-term testing.

Footnote \#9 - Deleted.

\section{$5.2 \quad$ Lakeside}

The recommended modifications to the proposed monitoring plan as listed in Table 3 are as follows. These modifications reflect haseline monitoring conducted for the Lakeside station. The following parameters have been added under the gaseous emissions category: $\mathrm{CO}_{2}, \mathrm{HC}$, Particulate 
Loading, Particle Size Distribution, Resistlvity, and $\mathrm{N}_{2} \mathrm{O}$. A Solid By-Product category has been added for the monitoring of ash. A Worker Health Category has been added for the monitoring of the following parameters: employee pulmonary function, hearing, and total suspended particulate. An Air category has been added for the monitoring of noise and ambient dust on-site. The sample type, frequency, and location for all additional parameters listed above are noted in Table 3.

The recommended modifications for the footnotes in Table 3 are as follows:

Footnote \#1- Ash will be monitored for the following parameters: mineral analysis, TCLP, total organic carbon, cyanide, chloride, sulfide, specific gravity, fineness, $\mathrm{PAH}$, and $\mathrm{Ph}$.

Footnote \#2 - Measurements will be taken once during Phase I.

Footnote \#3 - Must occur prior to initiation of Phase III.

The recommended modifications to the proposed monitoring plan as listed in Table 4 are as follows. The frequency of monitoring the sluice water intake and discharge as listed under supplemental water monitoring has been changed to more accurately reflect monitoring to be conducted during Phase III. The velocity measurement listed under the Gaseous Emissions monitoring for Phase III has been deleted due to the combined stack readings at Lakeside. The combined readings would not provide accurate data for conducting ambient air modeling for Unit \#7. The frequency of noise and ambient dust listed under Air monitoring in Phase III has been changed to more accurately reflect the testing schedule at Lakeside.

The recommended modifications for the footnotes in Table 4 are as follows:

Footnote \#1 - Measurements taken once during Phase III long-term testing.

Footnote $\# 2-\mathrm{N}_{2} \mathrm{O}$ measurements taken once during long-terms testing. Additional testing will then be done if the $\mathrm{N}_{2} \mathrm{O}$ concentration is greater than $5 \mathrm{ppm}$.

Footnote \#3 - Ash sampling will he conducted monthly for the first three months of the long-term testing period.

Footnote \#4 - Deleted. 


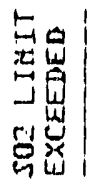

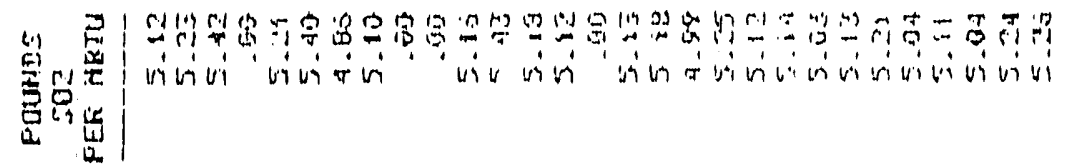

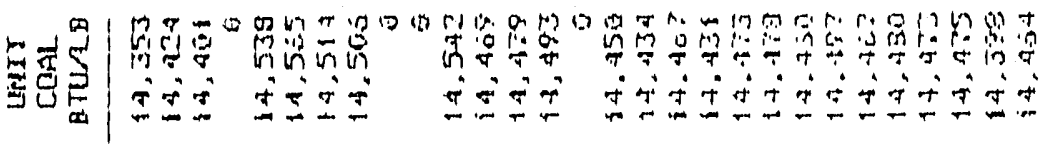

g

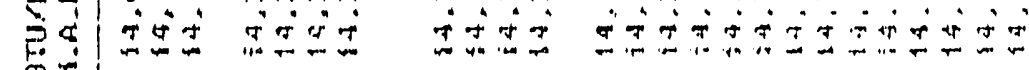

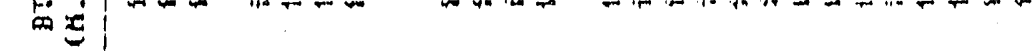
-

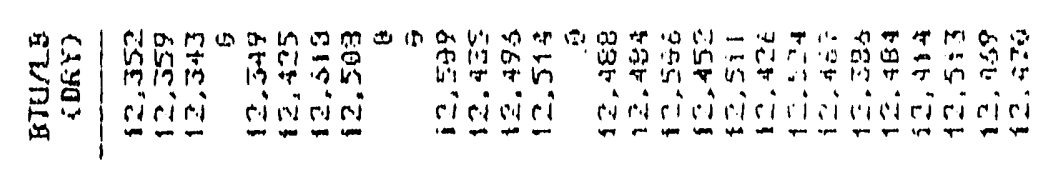

马 至

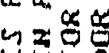

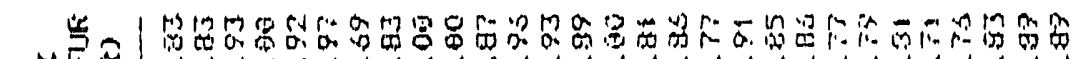

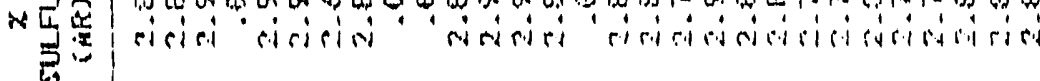

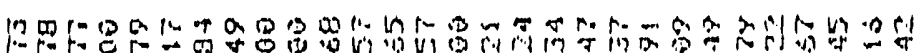

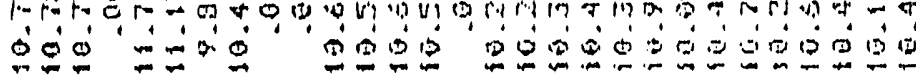

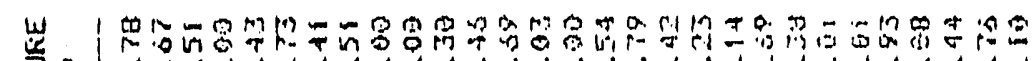
跎 总

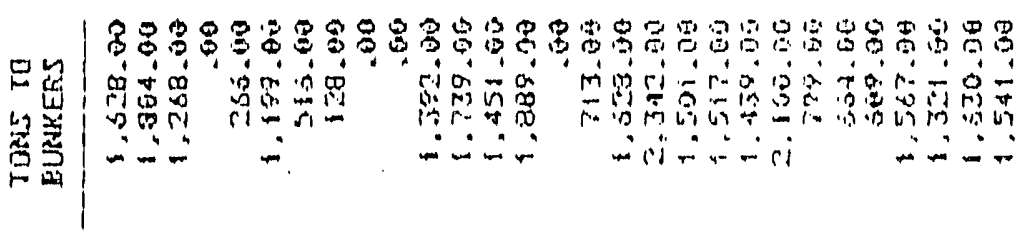

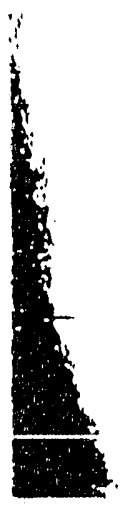

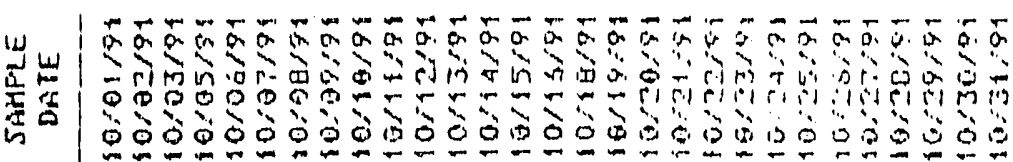

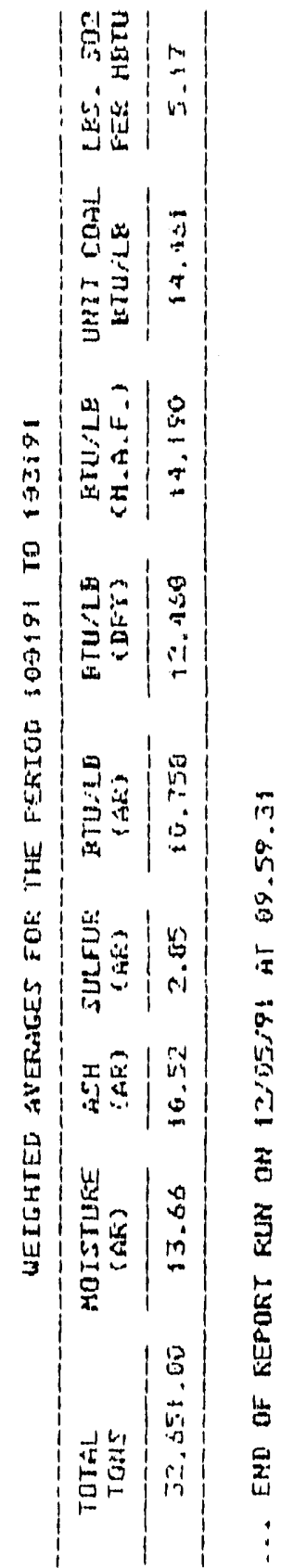


望罾|

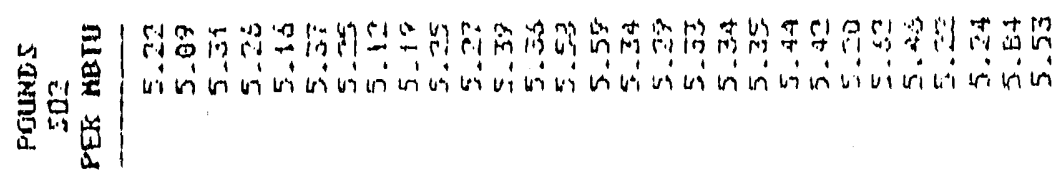

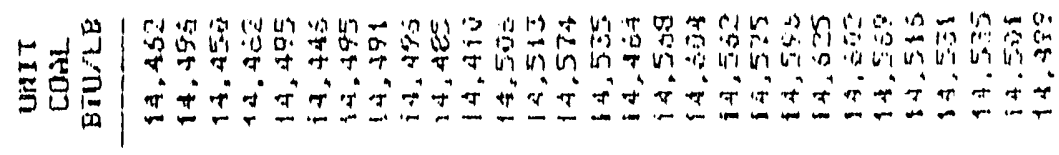

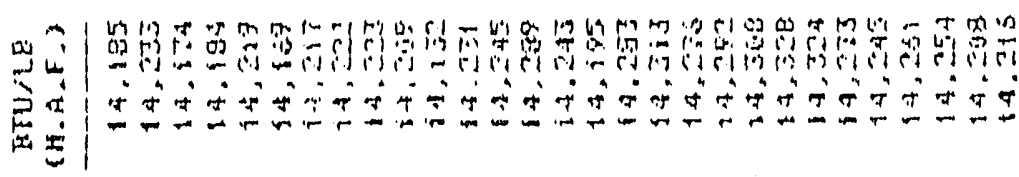

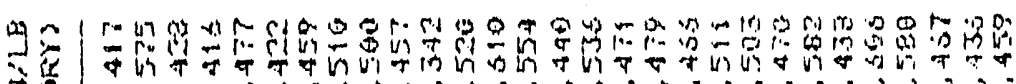

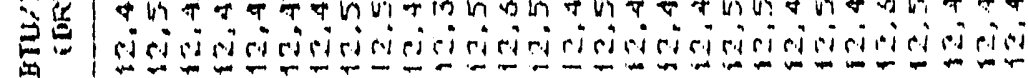

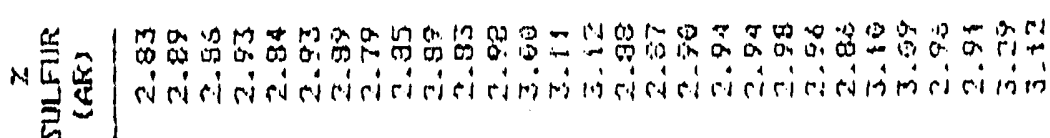

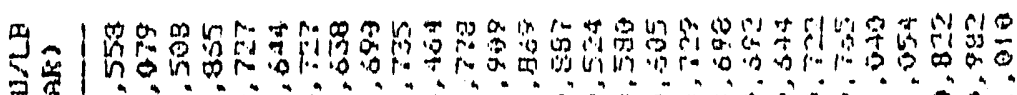
点 究它

\section{M䛼密}

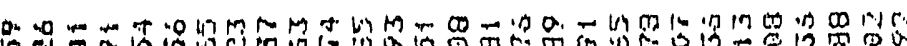

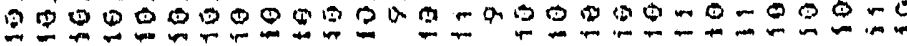

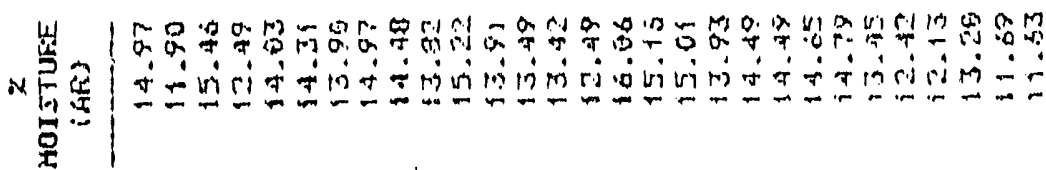

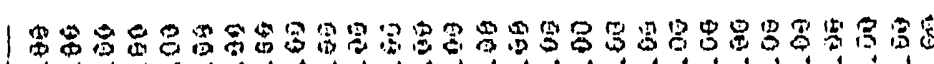

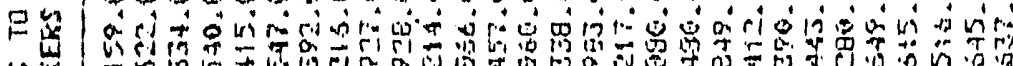

垈悹

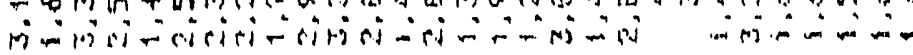

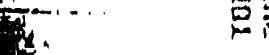

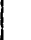

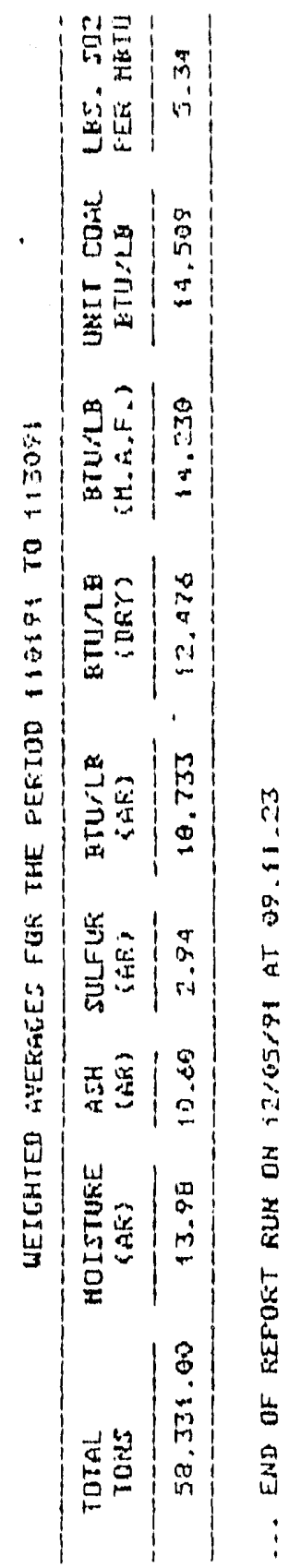




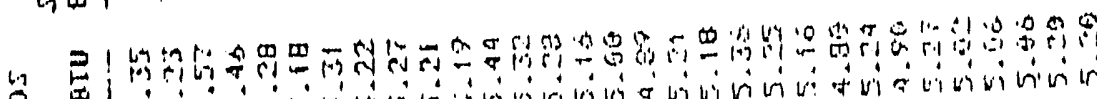

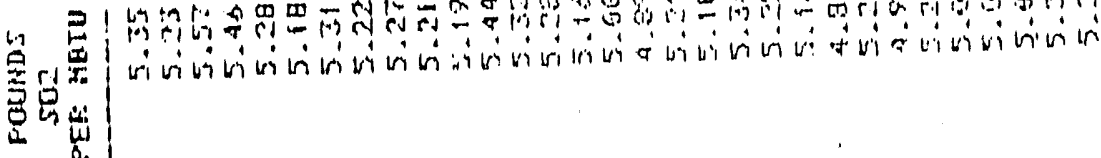

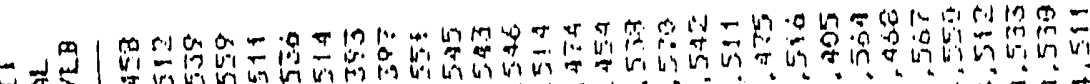

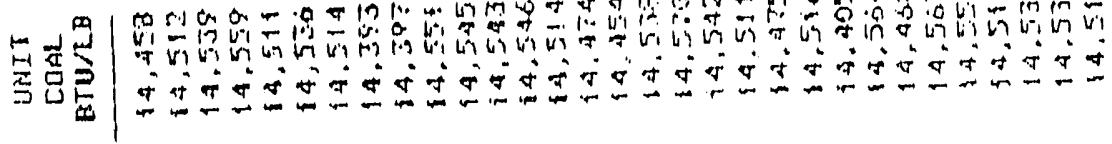

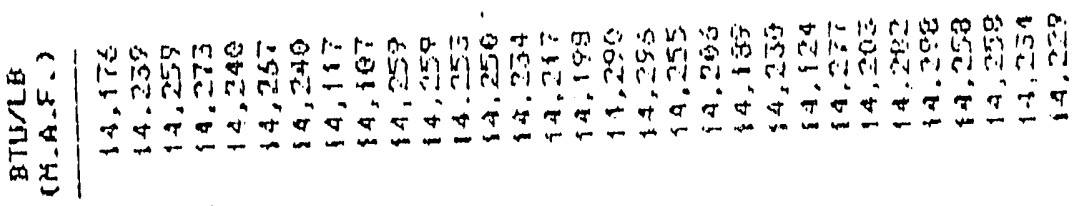

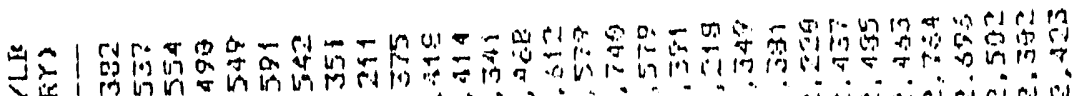
家 品

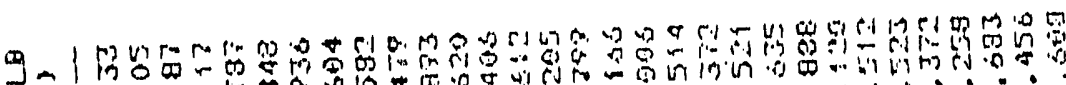
年等

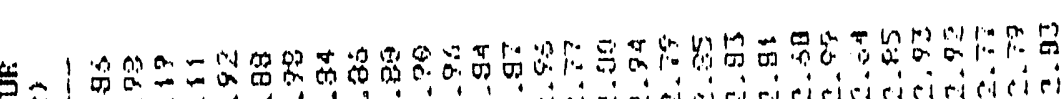

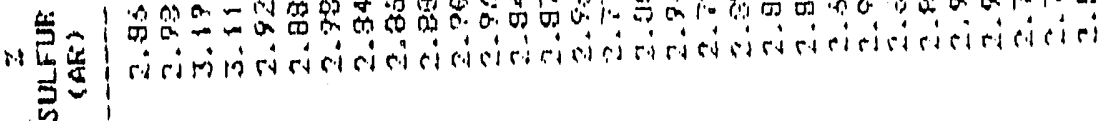

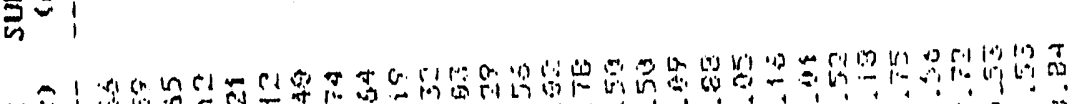
火焉

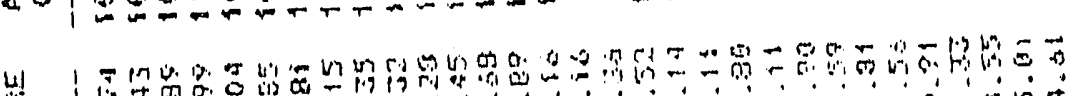

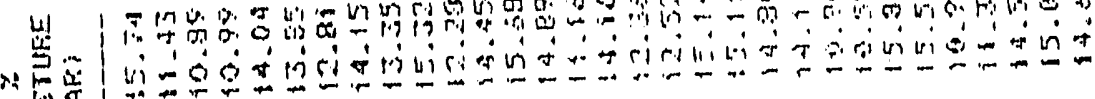
要

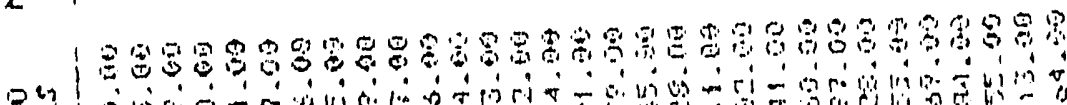

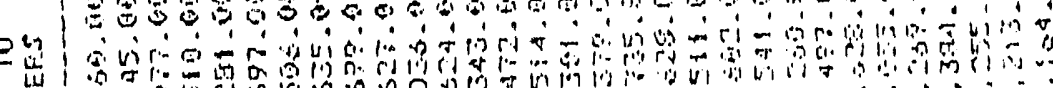

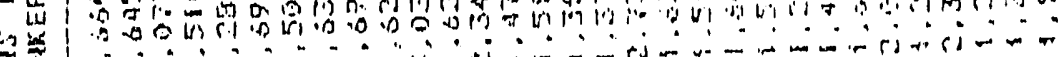

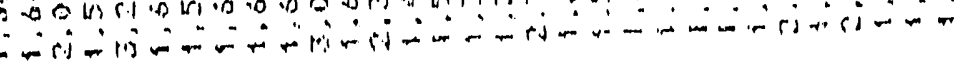




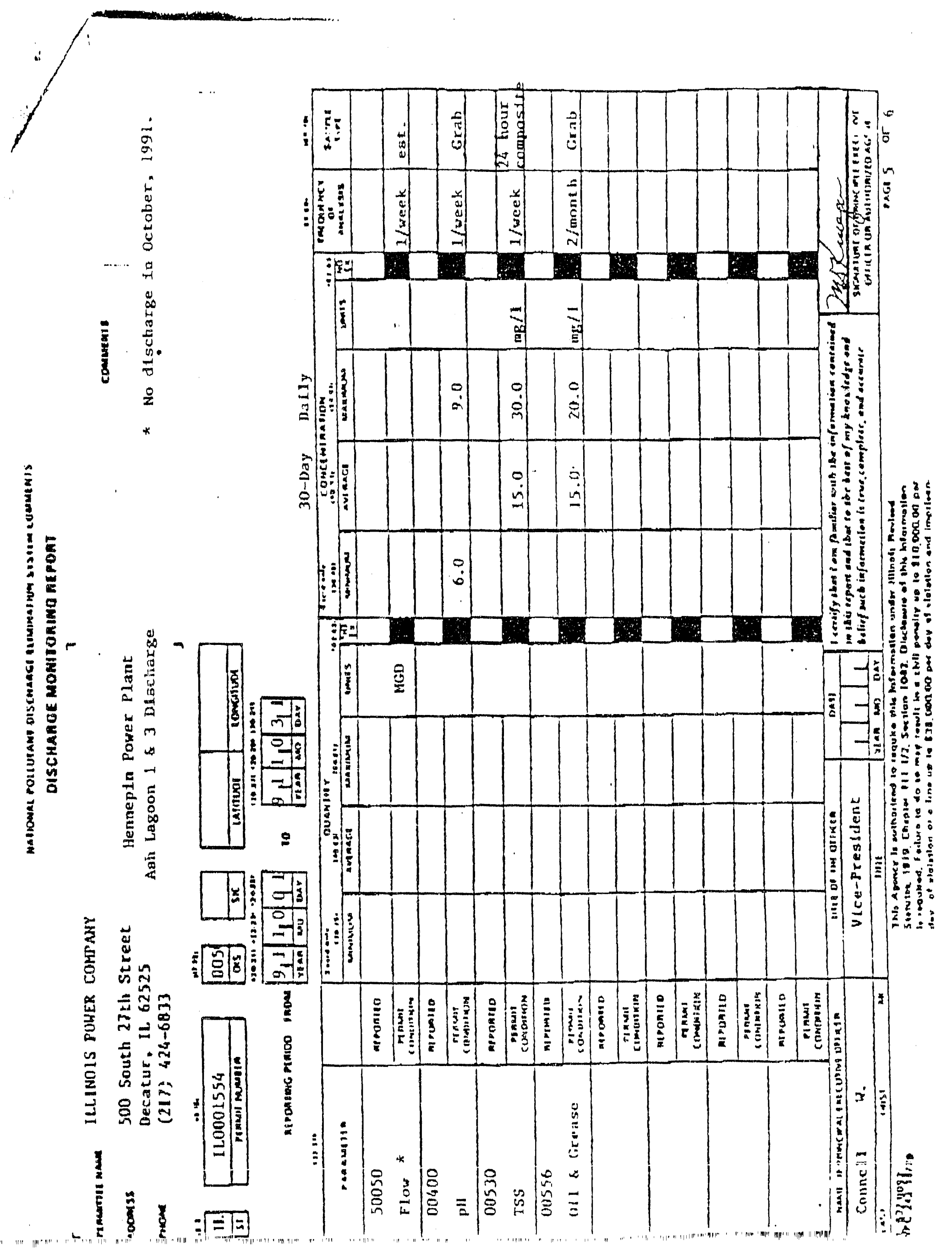




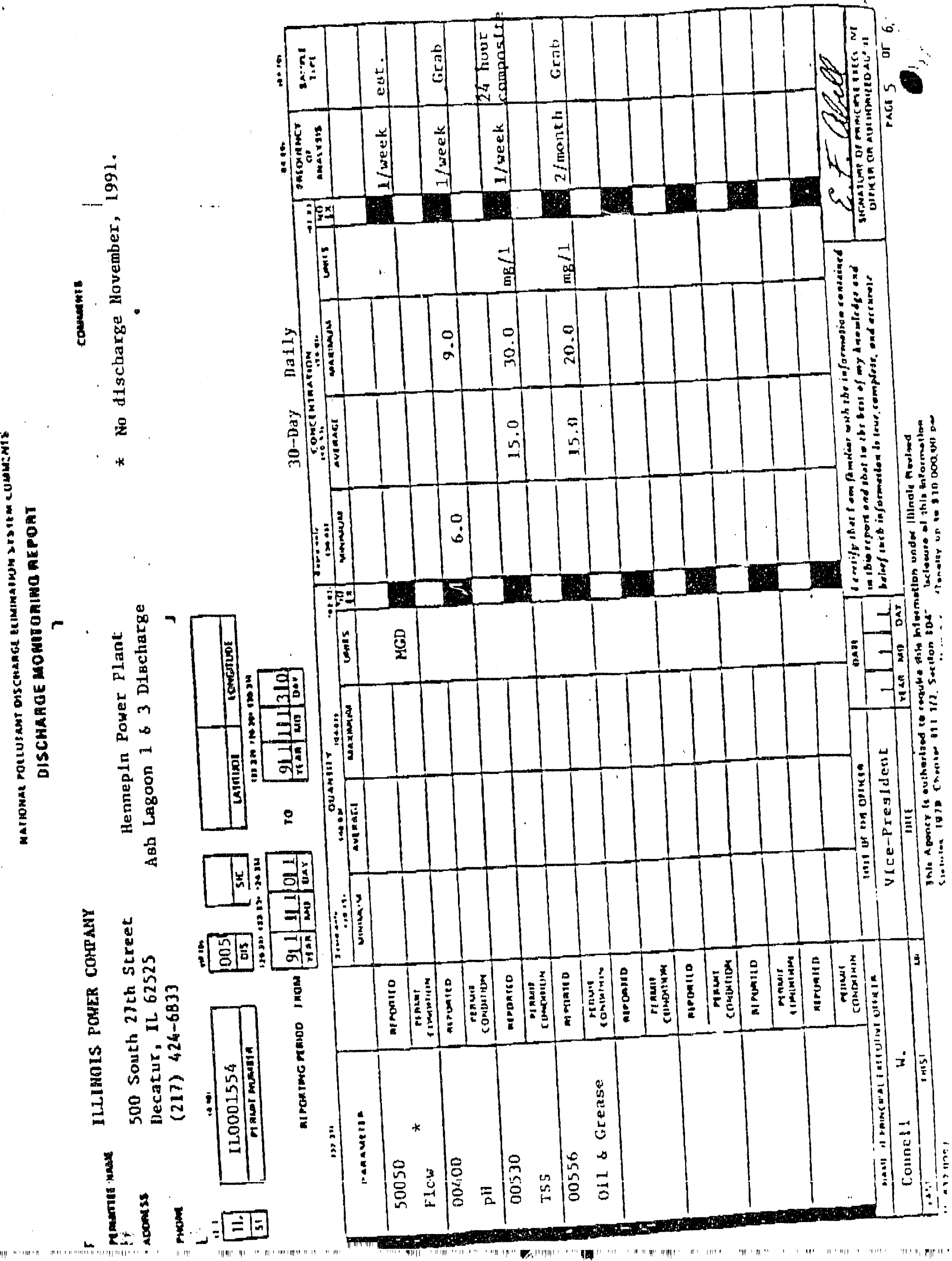



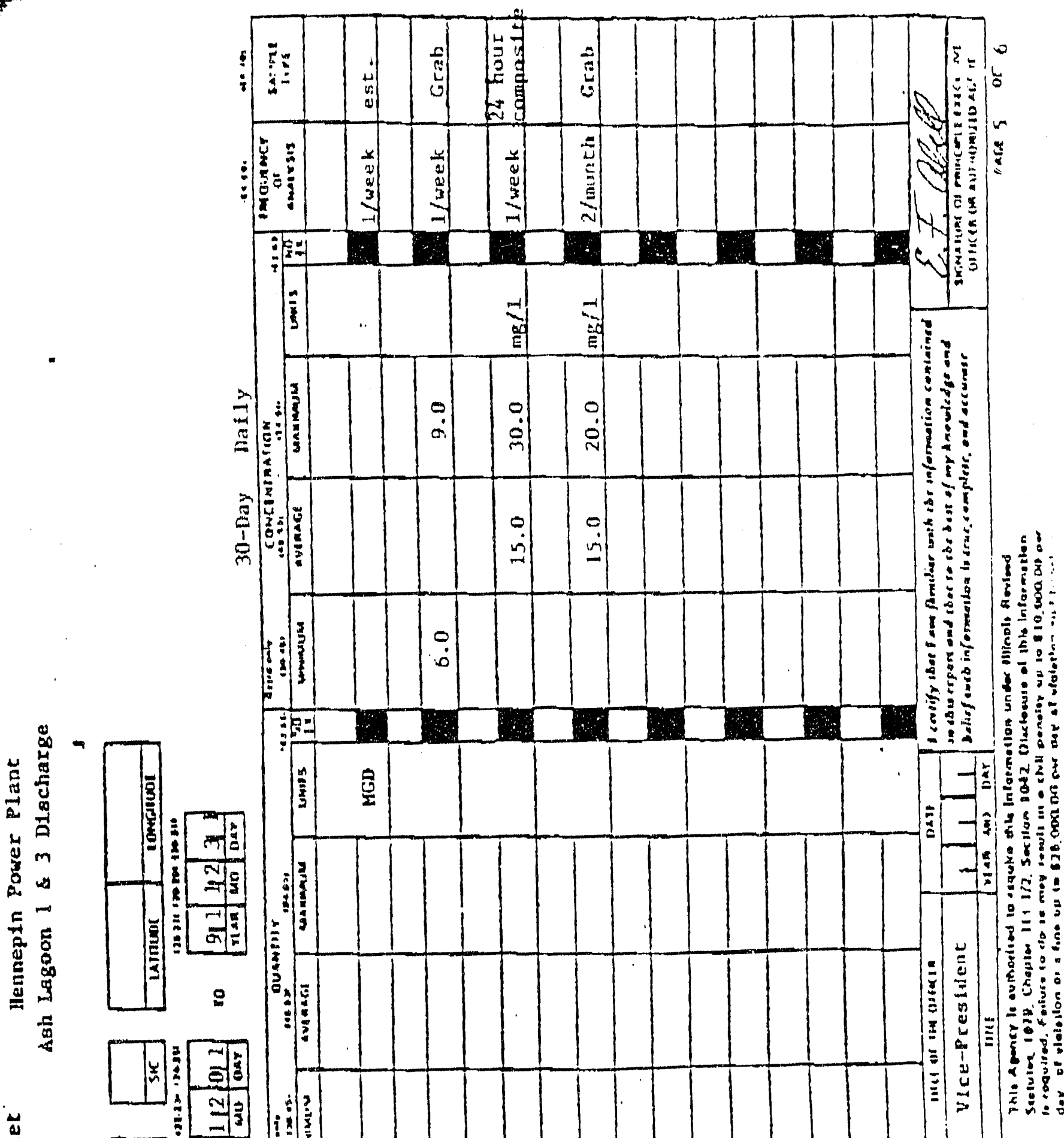

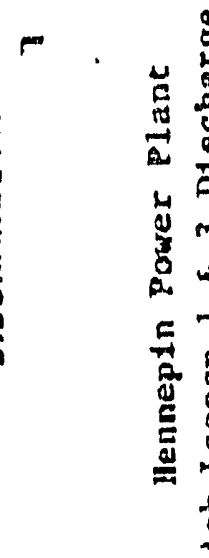

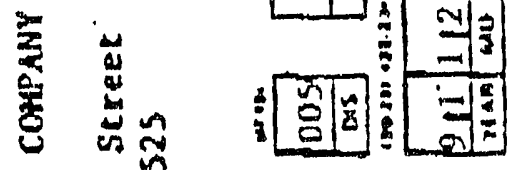

密

홀

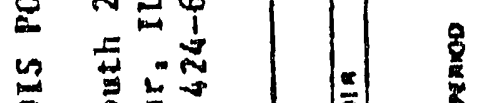

in

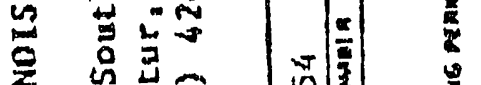

1

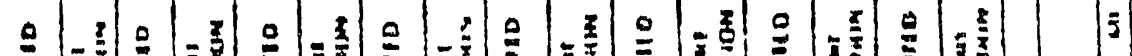

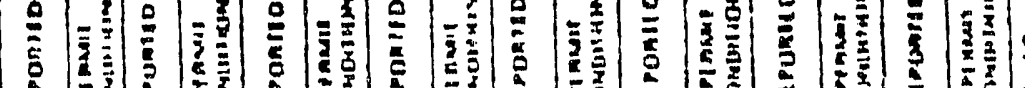

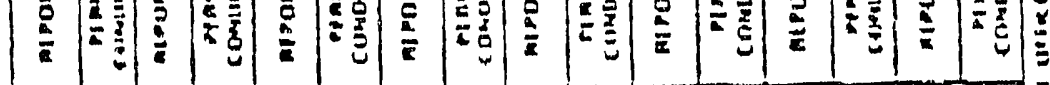

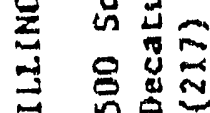

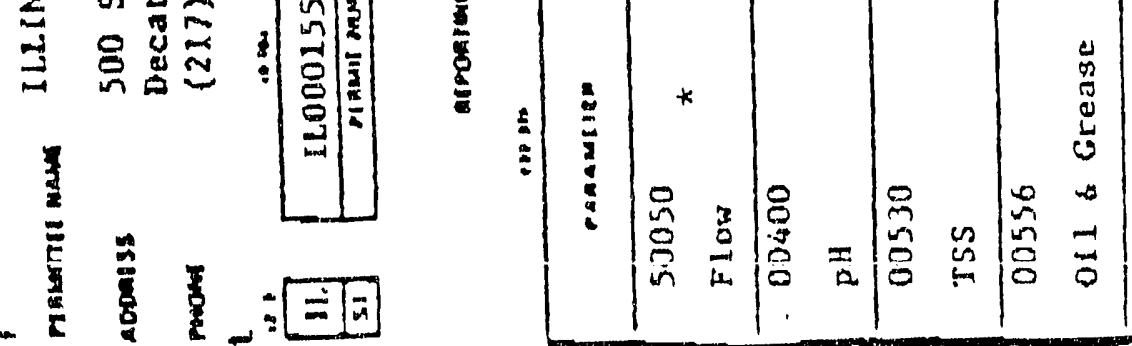


APPENDIX B 


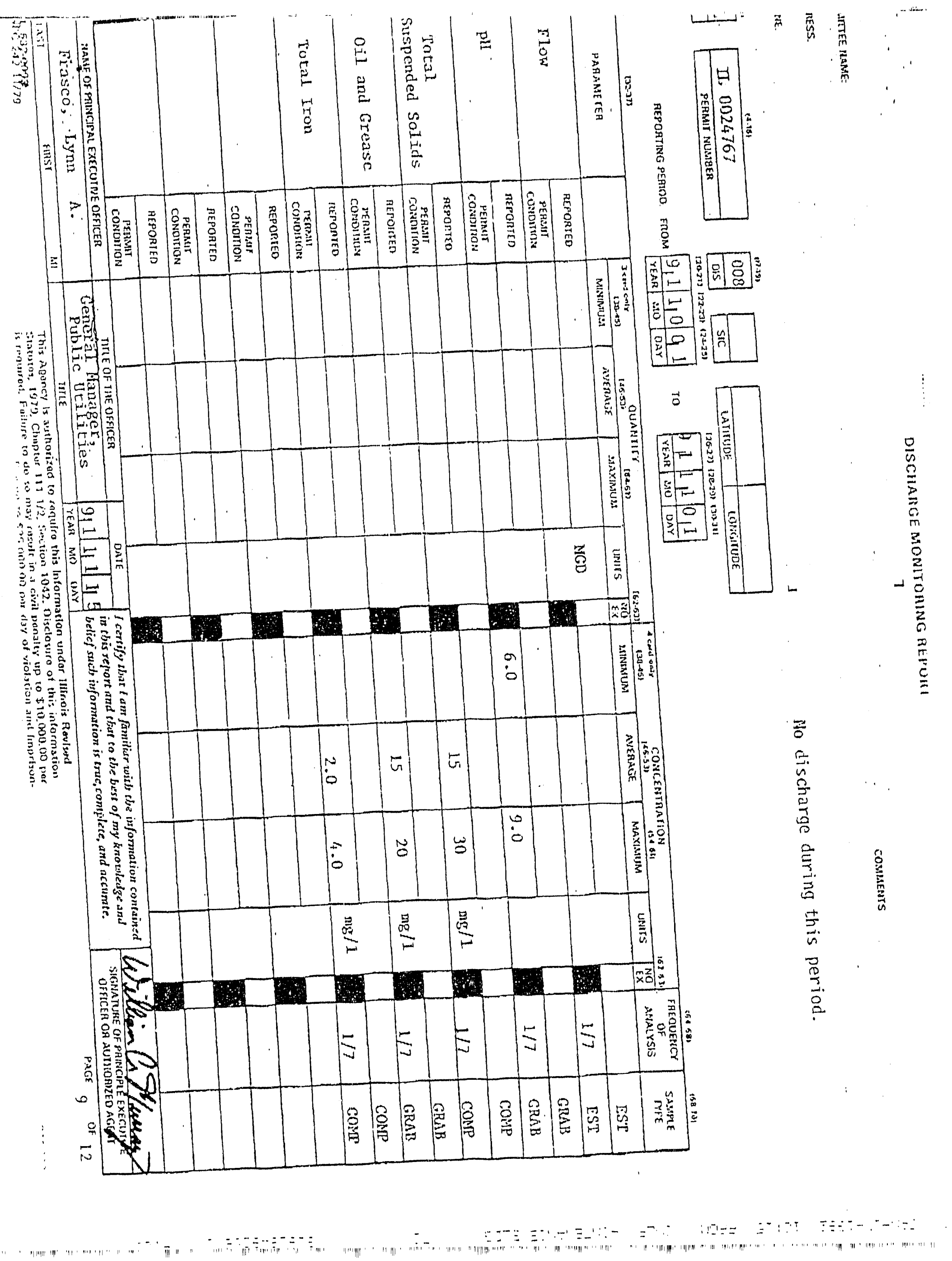




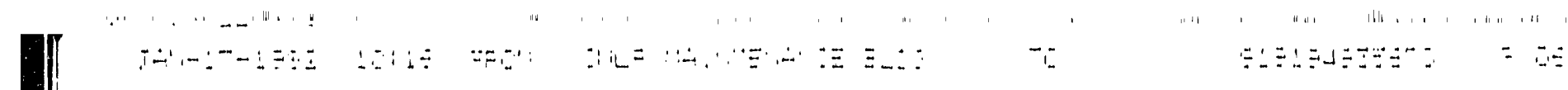

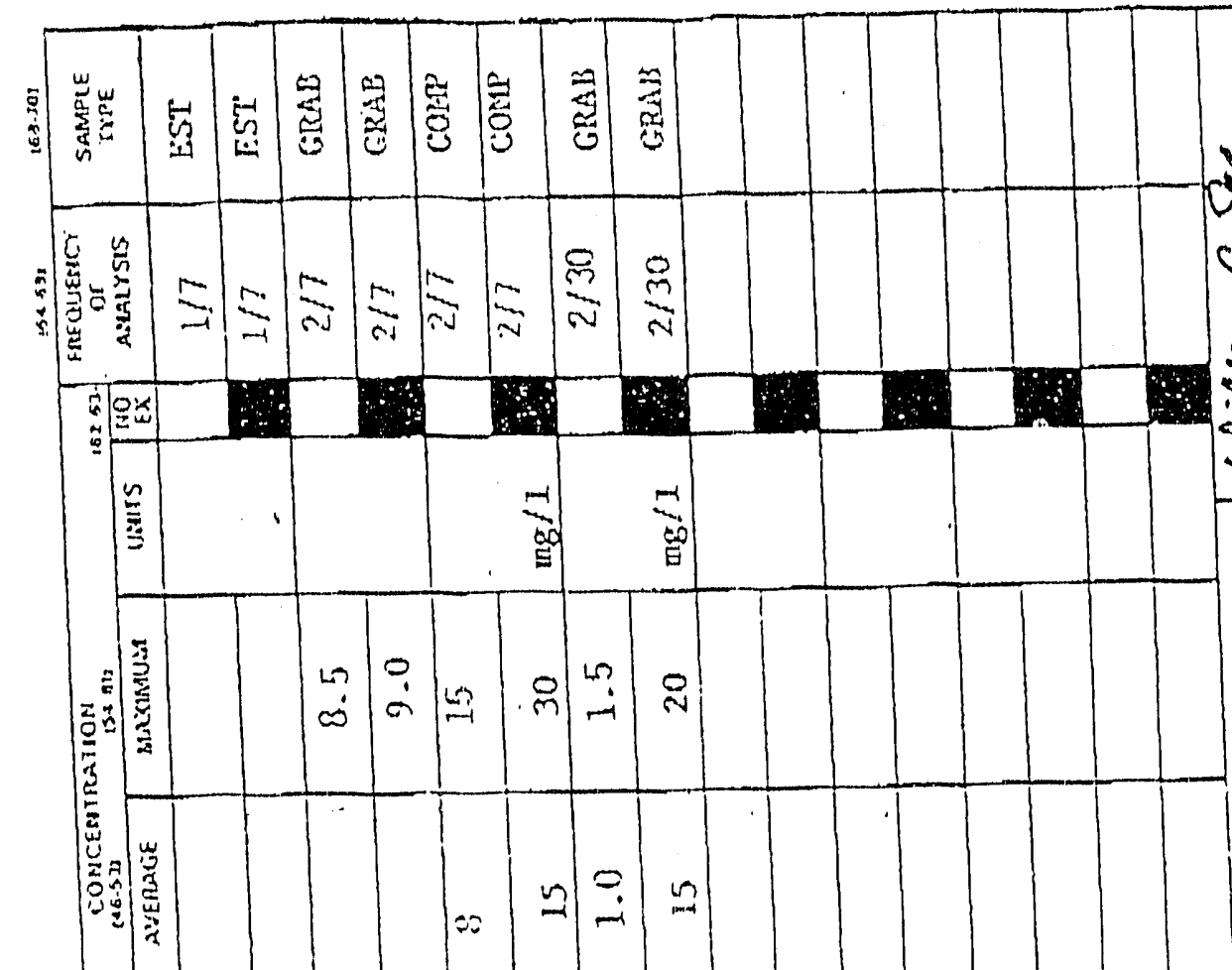

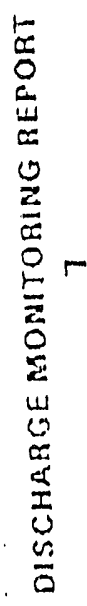
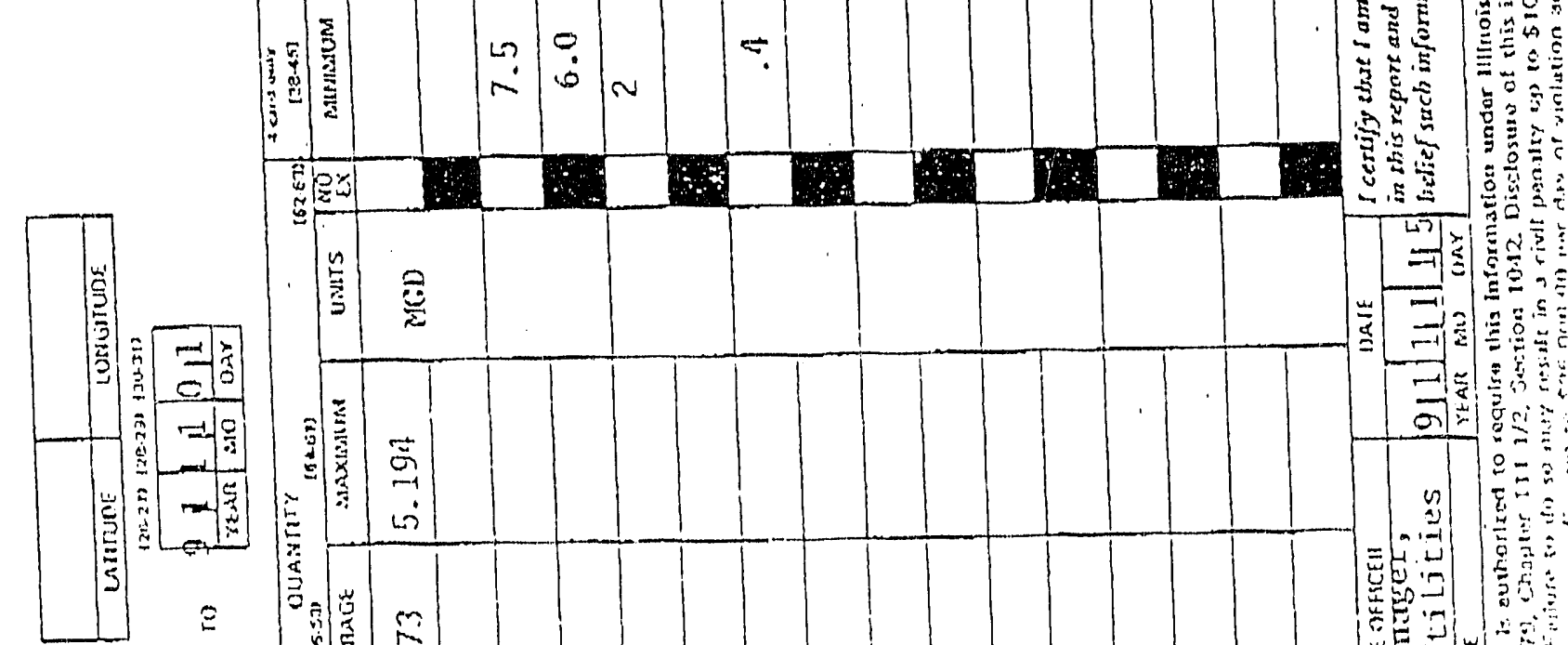

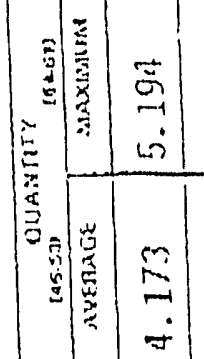

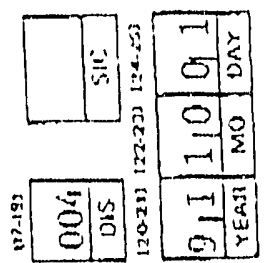

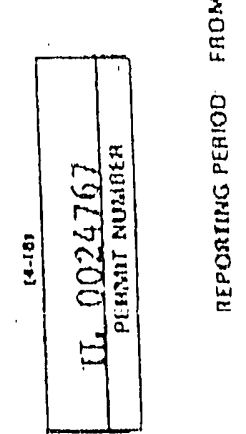

总

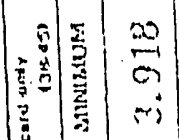

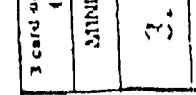

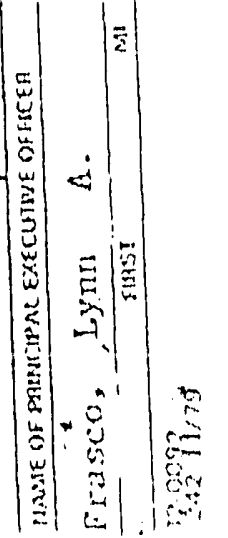




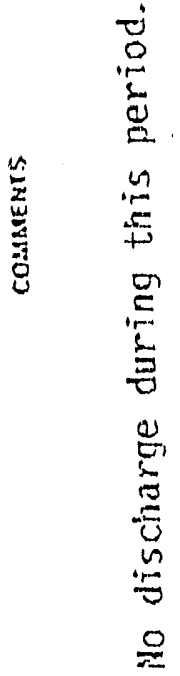

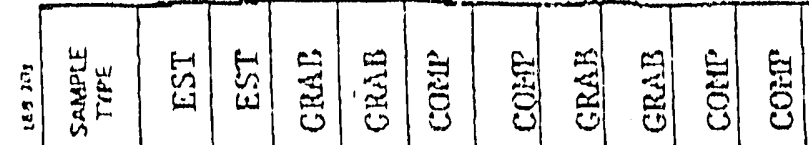

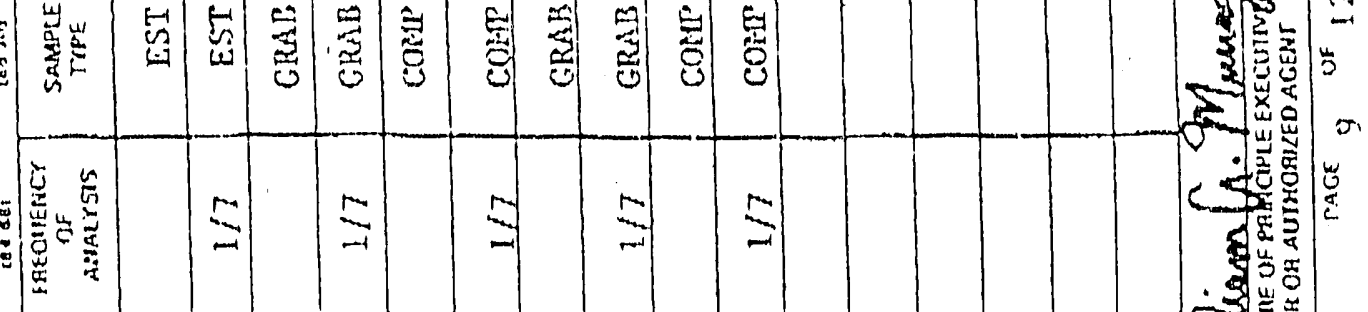

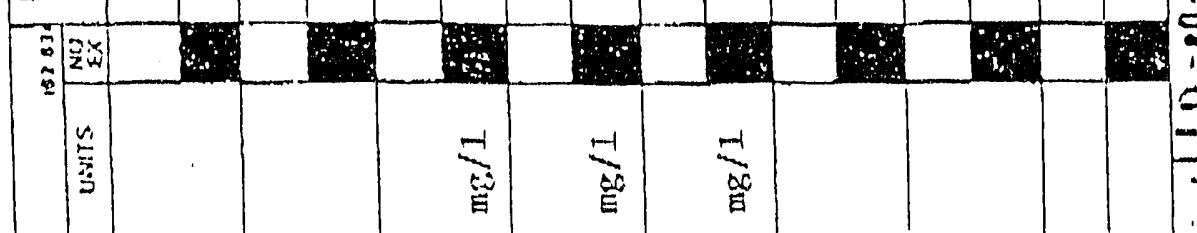

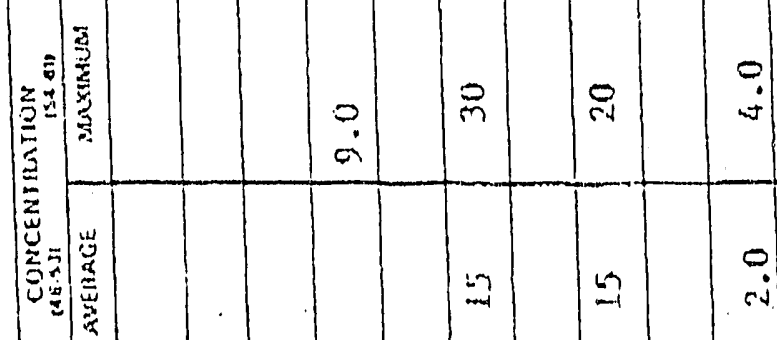

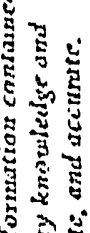

昰

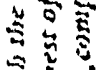

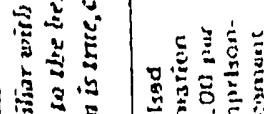

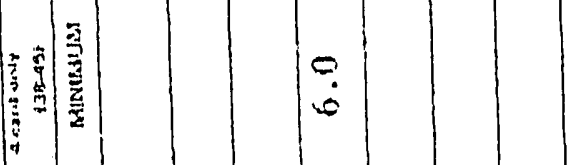

急范

落

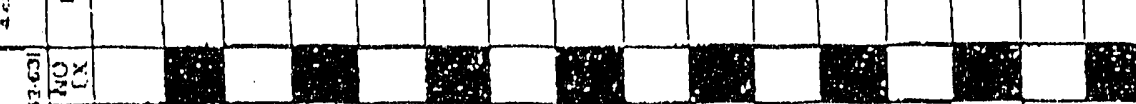

ษ

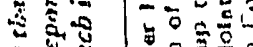

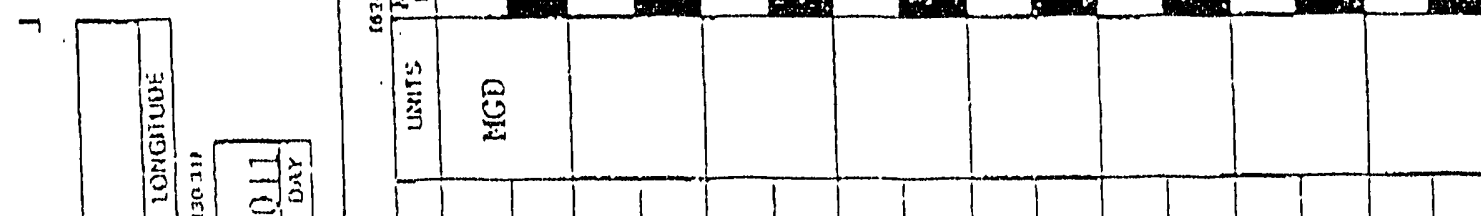

논

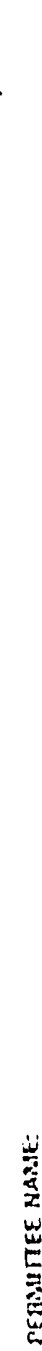

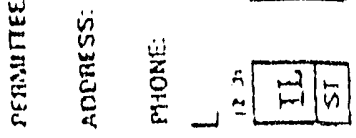
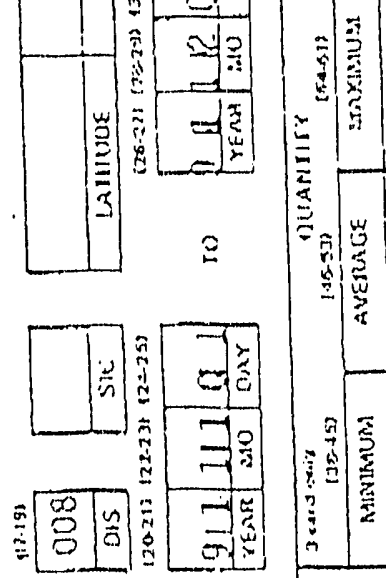

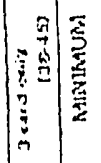
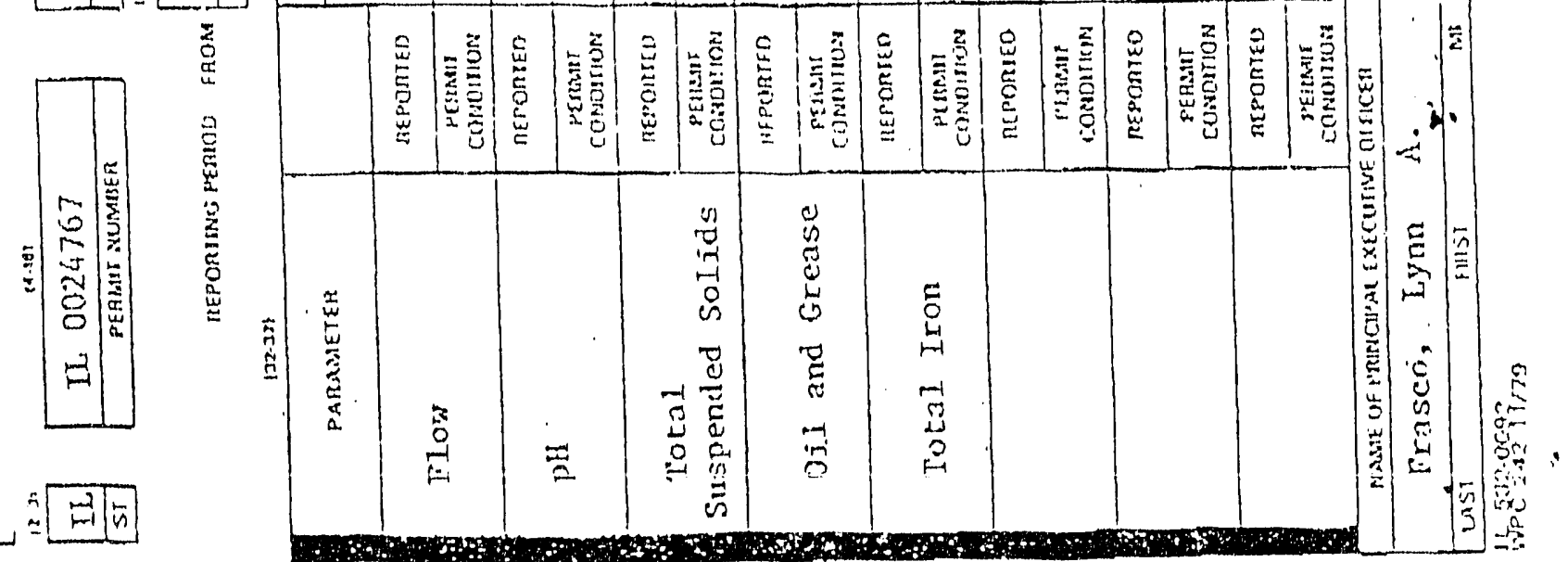


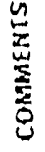

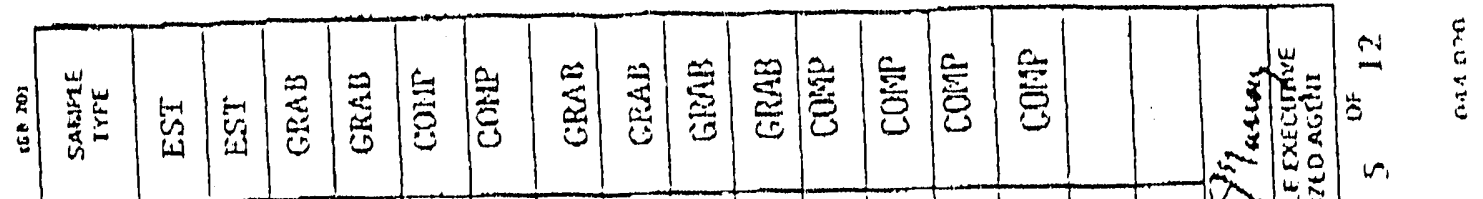

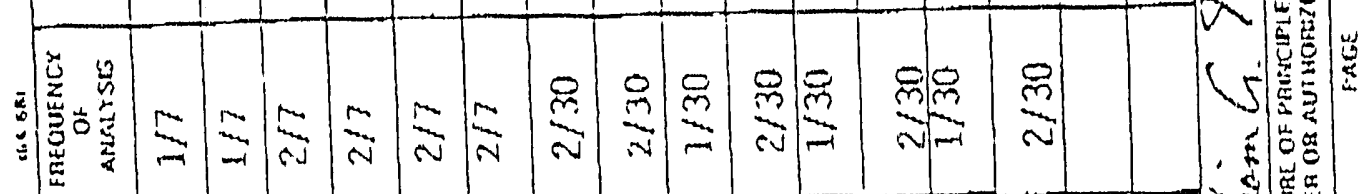

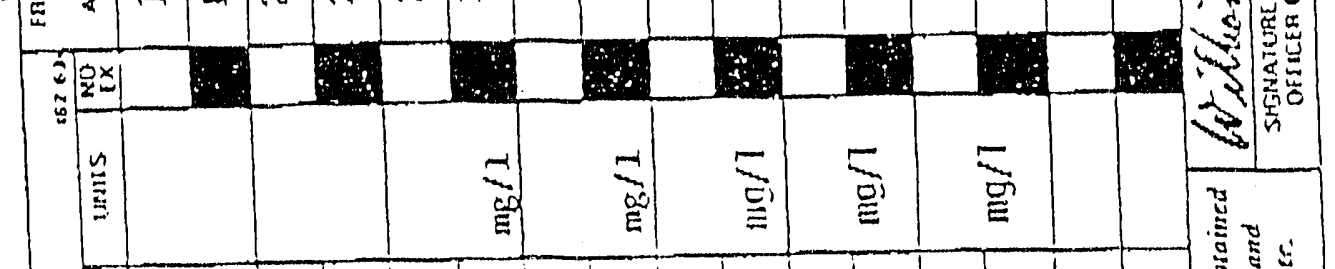

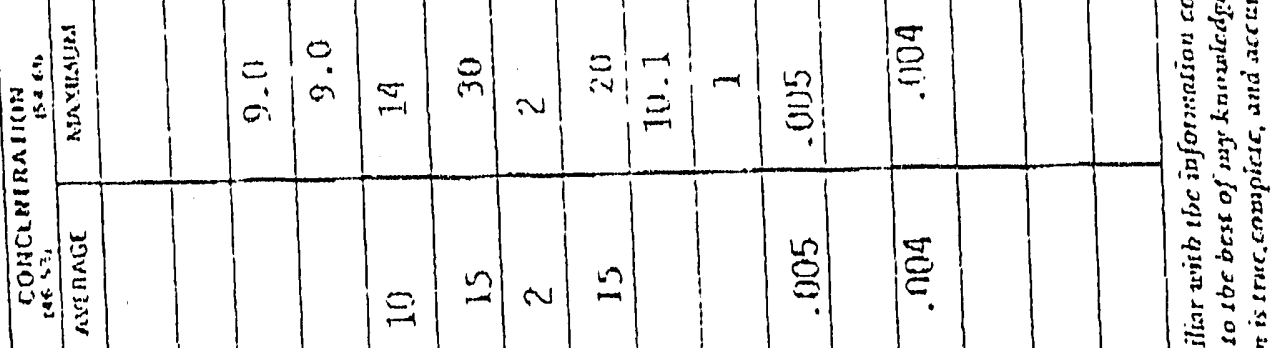

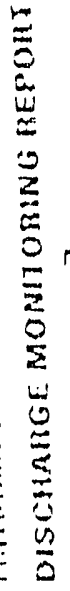

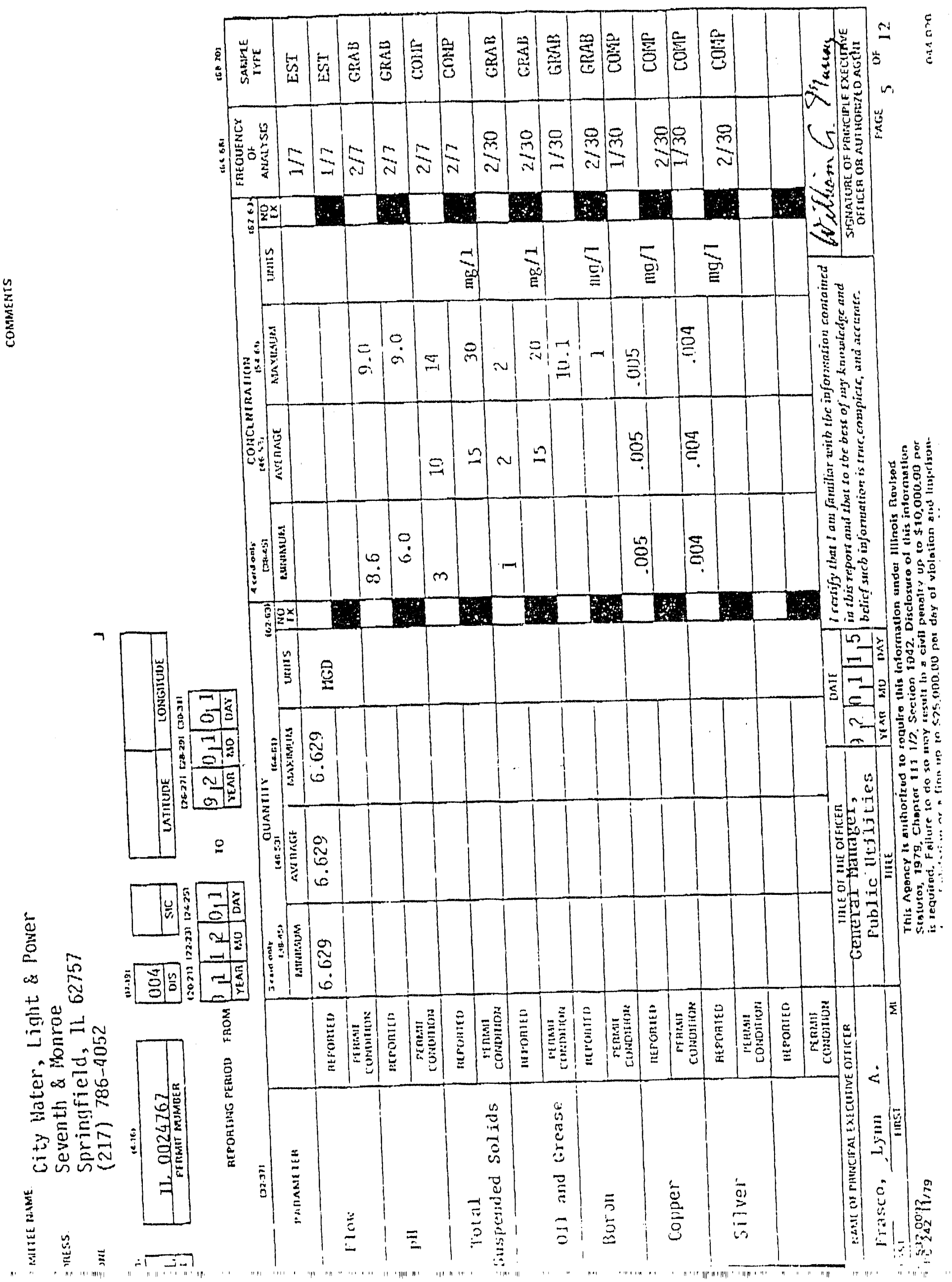




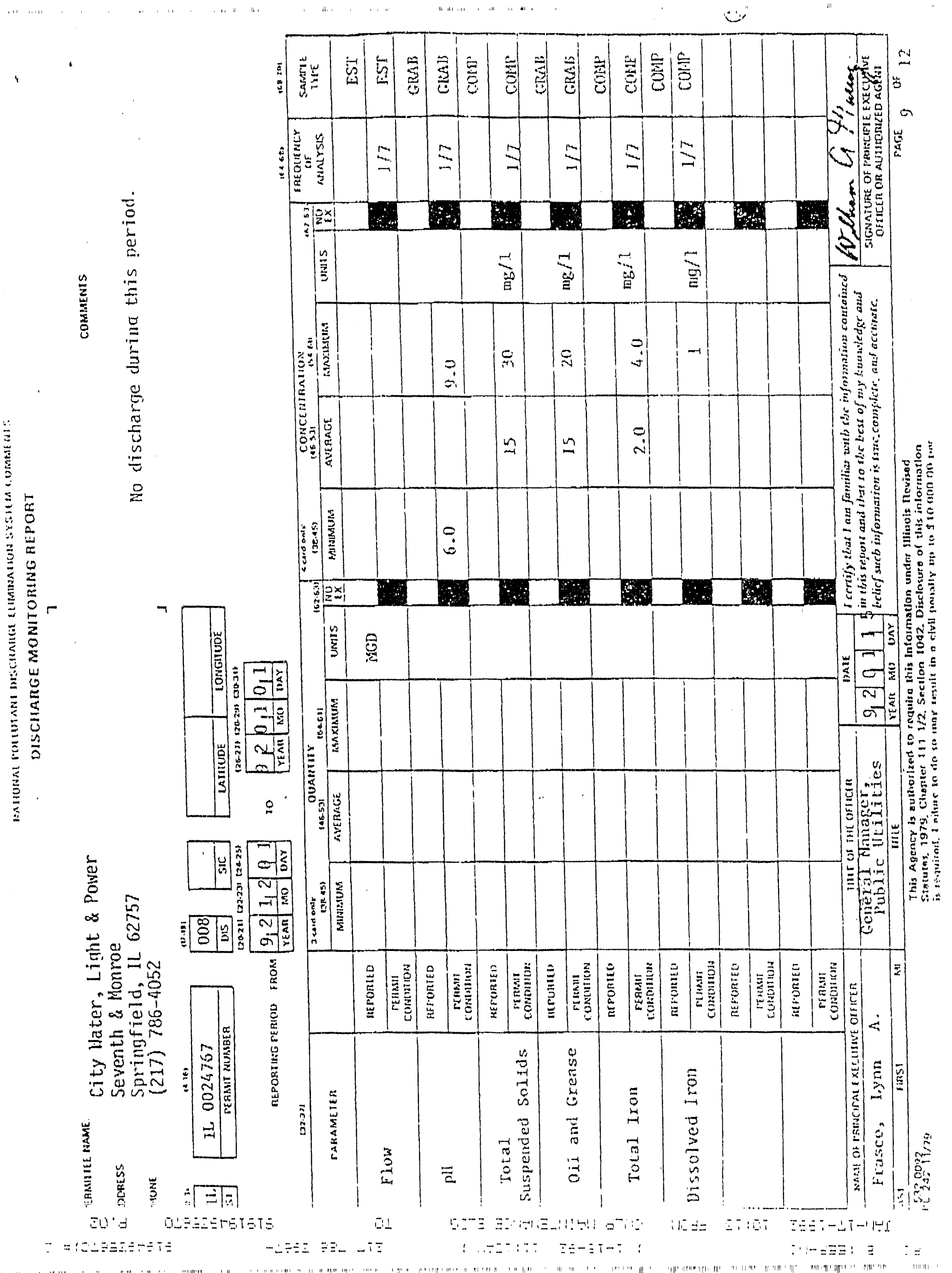




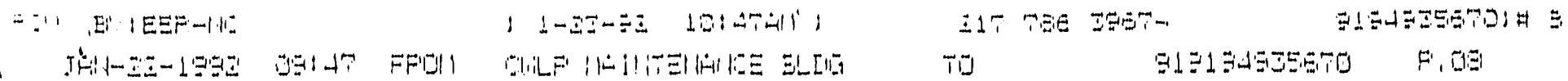

\section{CITY WALER, IIGHT \& DOHER}

3100 stevenson Drive

EXCESS ORACITY RERORT

Units (s) Lakeside

Oracity Iimit: $\quad 30 \%$

H7 Boller Hours: 212

Nonth/Year: Ootober 1991

$\| 8$ Eoider Holus: 92

\begin{tabular}{|c|c|c|c|c|}
\hline Eay & Start & opacity (\%) & Cause & $\begin{array}{l}\text { Corrective } \\
\text { Action Taken }\end{array}$ \\
\hline
\end{tabular}

$\begin{array}{llll}10-2 & 12: 54 & 35.0 & \text { Untirown }\end{array}$ 


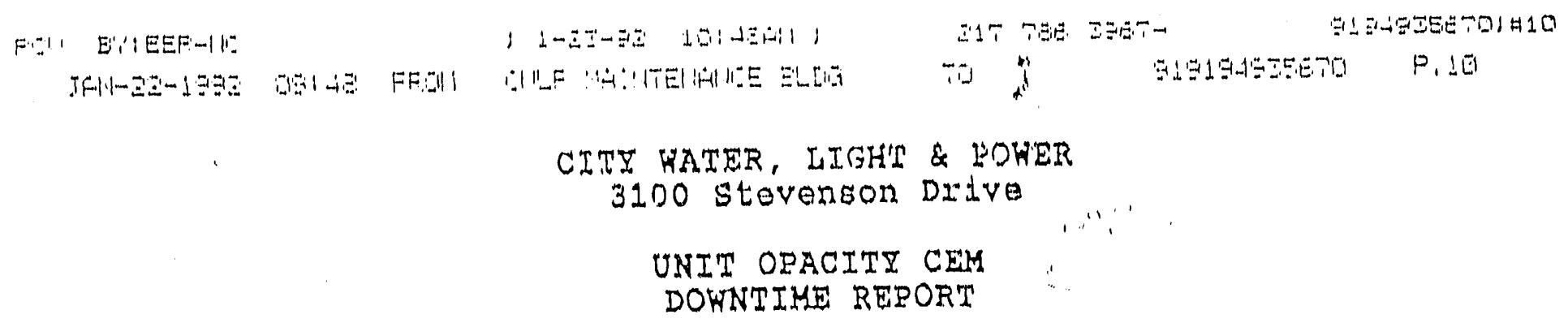

\begin{tabular}{lll} 
& Corrective \\
Date Stat-End & Component & Detion Taken \\
\hline
\end{tabular}

NON 


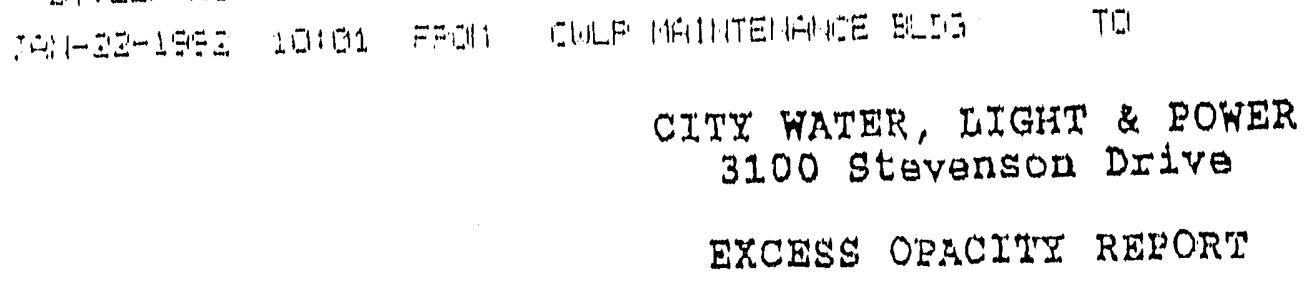

34.0

43.0

43.0

49.0

33.0

42.0

47.0

84.0

55.0

72.0

68.0

68.0

56.0

46.0

73.0

89.0

57.0

40.0

36.0

67.0

34.0

51.0

59.0

34.0

74.0

74.0

62.0

64.0

57.0

33.0
Startup 非
II
11
11
11
Shutdown il 7

startup $\$ 7$

"

11

"I

11

11

11

"1

II

II

11

"1

"1 


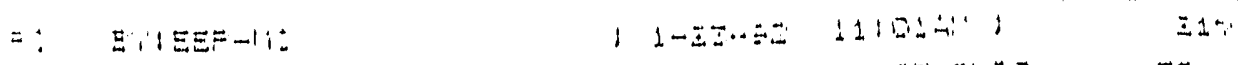

.

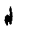

Excess Opacity Report

Lakeside - November 1991

Page $-2-$

\begin{tabular}{cccc}
\hline Start & Opacity $(\%)$ & Corrective & Action Tatien \\
\hline
\end{tabular}

$\begin{array}{rrr}10: 00 & 58.0 & 11 \\ 112 & 68.0 & 11 \\ : 18 & 67.0 & 11 \\ 11: 00 & 50.0 & 11 \\ : 06 & 60.0 & \end{array}$




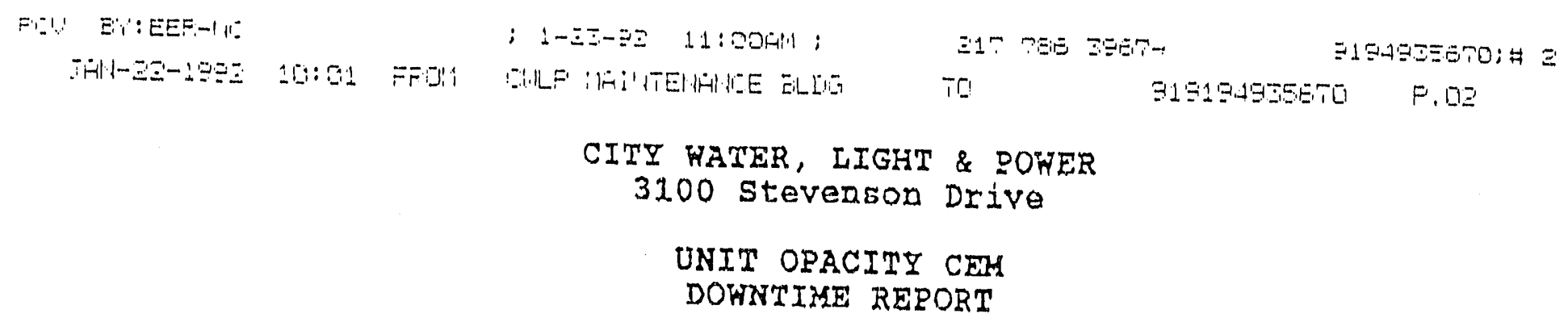

$N O N E$ 


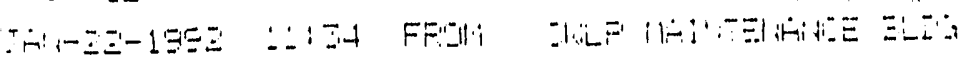

\section{CITY WATER, LIGHT \& POWER \\ 3100 Stevenson Drive}

\section{EXCESS OPACITY REPCRT}

$\operatorname{init}(s) \quad$ Lakeside

pacity Limit: $30 \%$

\#7 Boiler Hours: 168

Ionth/Year: December 1991

\#8 Boiler Hours: 125

\begin{tabular}{|c|c|}
\hline Start & Opacity $(\%)$ \\
\hline
\end{tabular}

\begin{tabular}{|c|c|c|c|}
\hline $\begin{array}{r}02: 18 \\
: 24 \\
03: 06 \\
04: 06 \\
: 30 \\
: 36 \\
09: 00 \\
: 06 \\
: 12 \\
10: 00 \\
: 18 \\
: 24 \\
: 30 \\
11: 00 \\
: 06 \\
: 12 \\
: 13 \\
: 24 \\
: 30 \\
: 36 \\
12: 30 \\
: 54 \\
13: 00 \\
: 36 \\
14: 00 \\
: 06 \\
22: 24 \\
: 30 \\
: 26 \\
: 42 \\
23: 00 \\
: 06 \\
: 12 \\
: 18 \\
: 24 \\
: 30 \\
: 36 \\
: 42 \\
: 48 \\
: 54\end{array}$ & $\begin{array}{l}39.0 \\
35.0 \\
33.0 \\
35.0 \\
34.0 \\
48.0 \\
52.0 \\
67.0 \\
60.0 \\
34.0 \\
40.0 \\
51.0 \\
36.0 \\
63.0 \\
62.0 \\
40.0 \\
65.0 \\
64.0 \\
59.0 \\
52.0 \\
63.0 \\
56.0 \\
50.0 \\
48.0 \\
37.0 \\
61.0 \\
37.0 \\
75.0 \\
84.0 \\
39.0 \\
34.0 \\
52.0 \\
62.0 \\
68.0 \\
67.0 \\
62.0 \\
67.0 \\
56.0 \\
69.0 \\
67.0\end{array}$ & 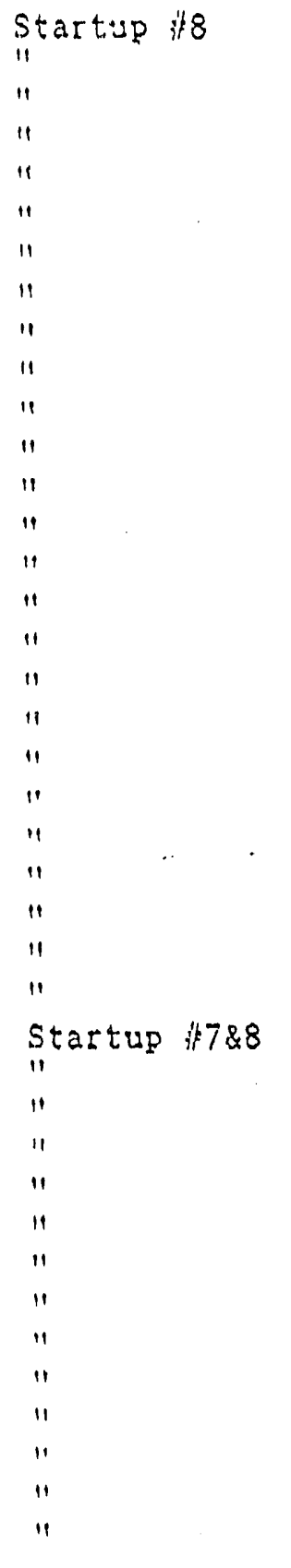 & ' \\
\hline
\end{tabular}


Exces Opacity Report

Lakeside - December 1991

Page -2-

Day Start $\quad$ Opacity $(\%)$ Cause $\quad \begin{gathered}\text { Corrective } \\ \text { Action Taken }\end{gathered}$

\begin{tabular}{|c|c|c|c|}
\hline $12-3$ & $\begin{array}{r}00: 00 \\
: 06 \\
: 12 \\
: 18 \\
: 24 \\
: 30 \\
: 36 \\
: 42 \\
05: 24 \\
: 30 \\
: 36 \\
: 42 \\
: 48 \\
: 54 \\
06: 00 \\
: 06 \\
: 12 \\
: 18 \\
07: 30 \\
: 36 \\
: 42 \\
08: 30 \\
: 36 \\
: 42 \\
: 48 \\
09: 00 \\
: 06 \\
: 12 \\
: 54 \\
10: 00 \\
: 06 \\
: 12\end{array}$ & $\begin{array}{l}58.0 \\
70.0 \\
65.0 \\
68.0 \\
45.0 \\
62.0 \\
66.0 \\
56.0 \\
51.0 \\
52.0 \\
63.0 \\
46.0 \\
54.0 \\
57.0 \\
36.0 \\
45.0 \\
71.0 \\
54.0 \\
75.0 \\
71.0 \\
49.0 \\
33.0 \\
63.0 \\
64.0 \\
41.0 \\
58.0 \\
68.0 \\
63.0 \\
50.0 \\
61.0 \\
63.0 \\
41.0\end{array}$ & 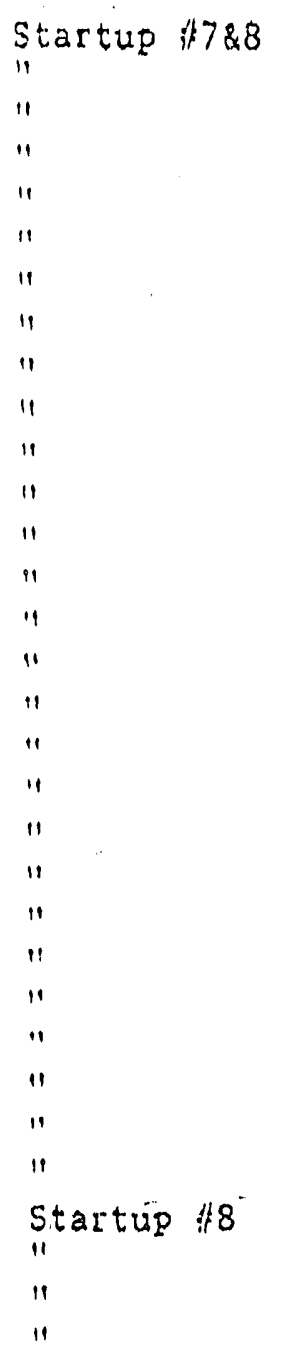 \\
\hline $12-4$ & $\begin{aligned} & 01:: 42 \\
&: 48 \\
&:: 54 \\
& 02: 00 \\
&: 18 \\
&: 24 \\
&: 30 \\
&: 42 \\
& 03: 06 \\
& 05: 54 \\
& 06: 00 \\
&: 06 \\
&: 18\end{aligned}$ & $\begin{array}{l}64.0 \\
40.0 \\
54.0 \\
35.0 \\
32.0 \\
59.0 \\
67.0 \\
32.0 \\
34.0 \\
36.0 \\
60.0 \\
38.0 \\
36.0\end{array}$ & $\begin{array}{l}\text { Startisp } \$ 18 \\
" 1 \\
" 1 \\
" 1 \\
" 1 \\
" 1 \\
" \\
" \\
\text { Startup } \| 7 \\
" 1 " \\
"\end{array}$ \\
\hline
\end{tabular}




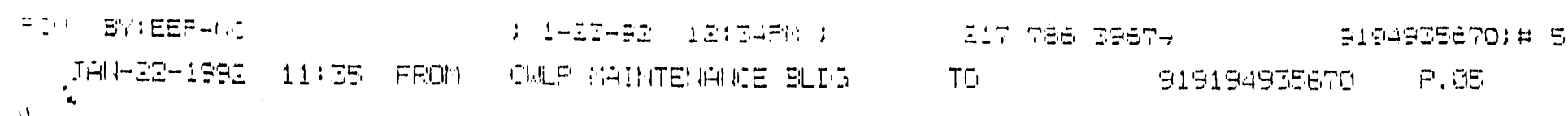

Excess Opacity Report

Lakeside - Decerber 1991

Page -3-

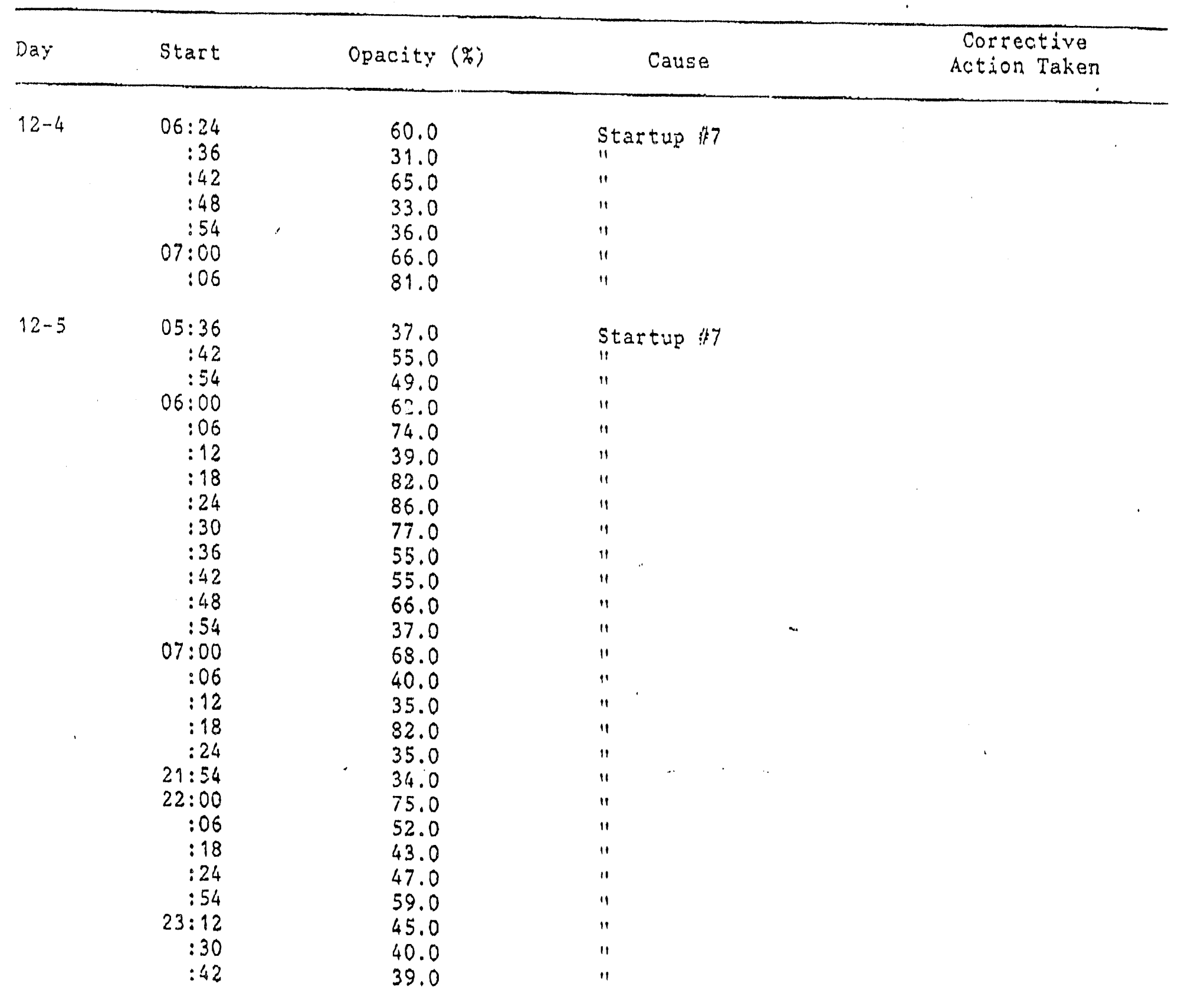

$12-6$

$$
\begin{array}{r}
05: 18 \\
: 24 \\
: 30 \\
: 36 \\
: 42 \\
: 54 \\
06: 00 \\
: 12 \\
:: 18 \\
: 24
\end{array}
$$

65.0

50.0

33.0

63.0

33.0

46.0

35.0

31.0

50.0

33.0

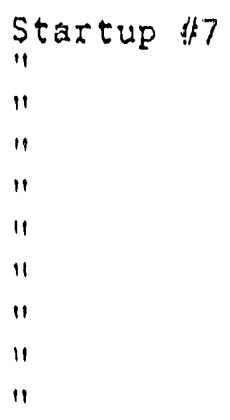




\section{CITY WATER, IIGHT \& POWER \\ 3100 stevenson Drive \\ UNIT OPACITY CEM \\ DOWNTIME REPORT}

Units) Lakeside

Month/Year December 1991

$\begin{array}{llll}\text { Date } & \text { Start-End } & \text { Component } & \text { Cause } \\ 12 / 17 & 03: 48> & \text { Transmissometer } & \begin{array}{l}\text { Malfunctioning } \\ \text { Board }\end{array}\end{array}$

Corrective

Action Taker

$12 / 18$

$09: 547$

$12 / 20$

$16: 00$

Transmissometer Malfunctioning

Replaced ma: Board

Replaced ma: board

board 
APPENDIX C 
Energy I Enyironuentad ipscaren

Continuous Ealssion: Manitorlin

Thirty Second Ayeregge Lata

Dater 30 Septenter 19:1 iast ilo.

Pianter Lakeside Lnit No.7

Loagr 33 w

Plant ce Layel: Norral

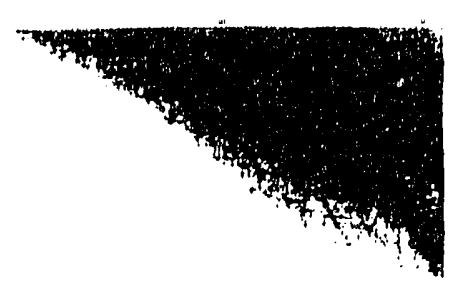

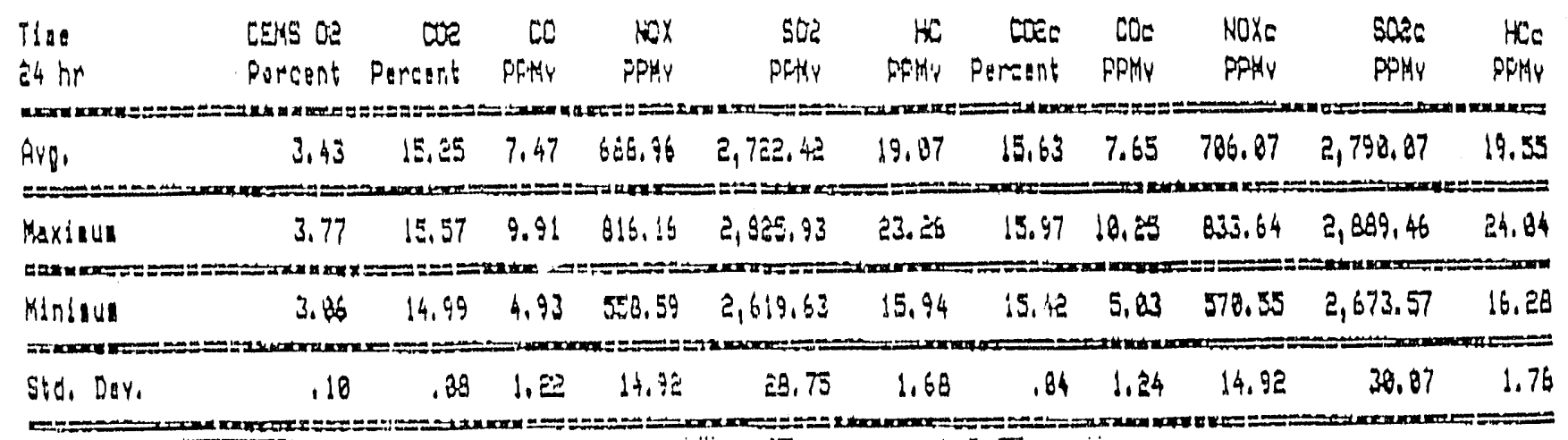

Energy f Erryironsentad Research

Continuous Eniss!cis Honitering

Thithy Second Average Dets

Data: OL Detober ?1 iest No, 2

Plants Lekesidg Lnit No.7

Load $33 \mathrm{KWH}$

Plant as Levali Noran!

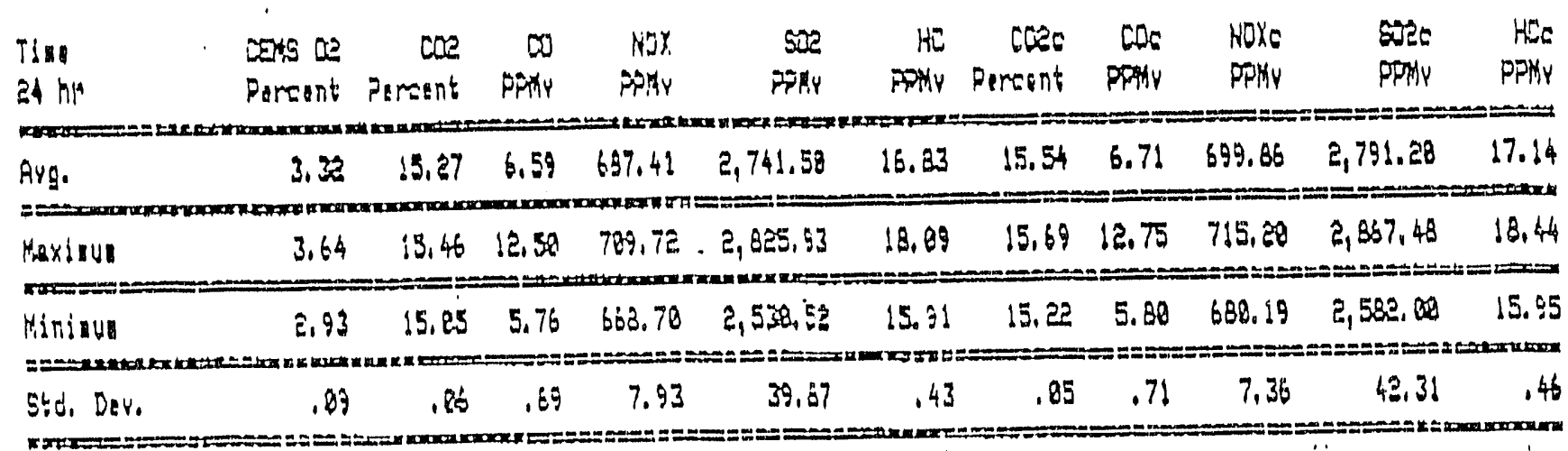

Energy \& Erivironagotad Rescerm

Continuous Ealssions Mor.ttoring

Thirey Secend paverago Dota

Date: Be Decoer i! iest No. 3

filant: Lakeside inat No.7

Loec: $35 \mathrm{Min}$

P! ant de Lavels Horral

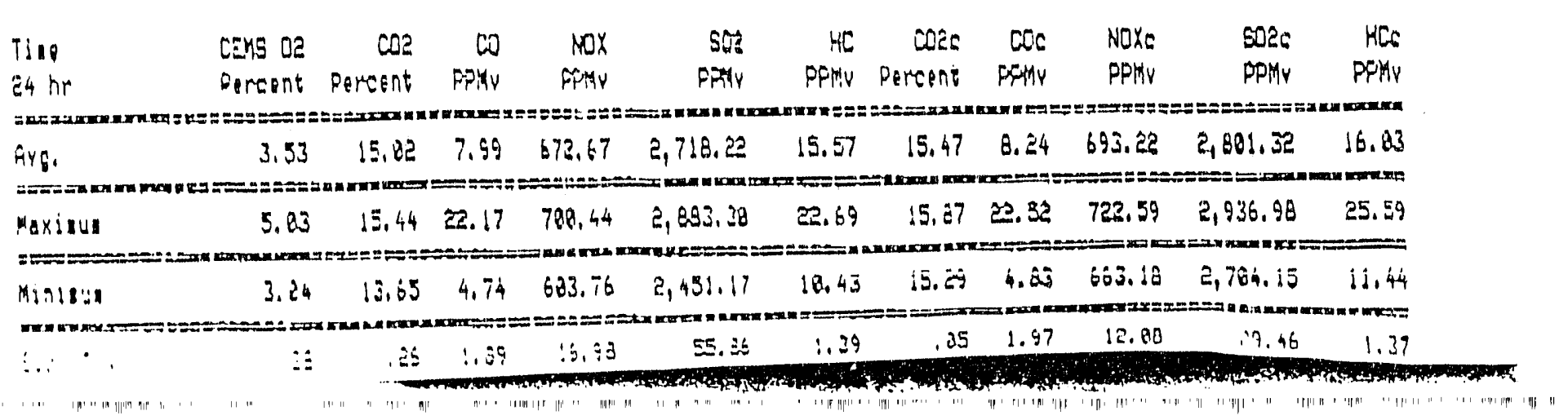


- cuvaronantal Resparch

continuous Endssicns Mondisring

Trijty Second Ryerage Data
Test No.

Flanb: Lakesid Unit Ho.7

Loadi as in

plant oe Leyell horwal

Catei

Q3 Oetober 91

Tis:

$24 \mathrm{hr}$ CEMS CA COE

ED NoY

SOD HC COEC

$C D$

pepty Ppity fiersont

PFil

Noxc

Pithy

SDEE HCE

Pereent Derent Privi Piv

10,84

15.58

$\begin{array}{llll}5.74 \quad 634,89 & 3.779,65 \quad 11.14\end{array}$

Riv.

$3.43 \quad 15.16$

¿.55 be1.54 $2,724,53$

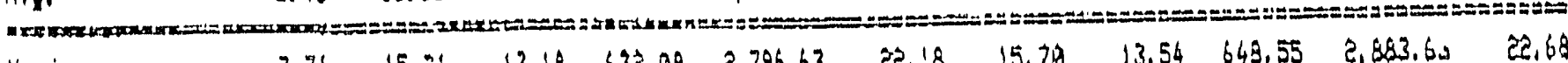

Maxisus

3.91

15.31

$13.18 \quad 632.09 \quad 2,796.63$

已ᄅ! !8

15.70

$2.14 \quad 15.48$

$15.48 \quad 4.88 \quad 619.46 \quad 2,559.60 \quad 9.3$

Pininus

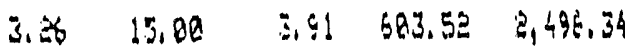

47,30

3.12

.65

l. $\tilde{C}_{4}$

5.12

55.27

sivg, DRY,

189

$.86 \quad 1.28 \quad 4.37$

$-$

$-m-m-m$

Test Ho.

Planti Lakesido linit Ho.?

Eneray Environothed Raseerain

Continuous Exissions Minitoring

Thirty Sucand Averse Data

L.028: $25 \mathrm{WH}$

Plant Ca. Leyed: Noryad

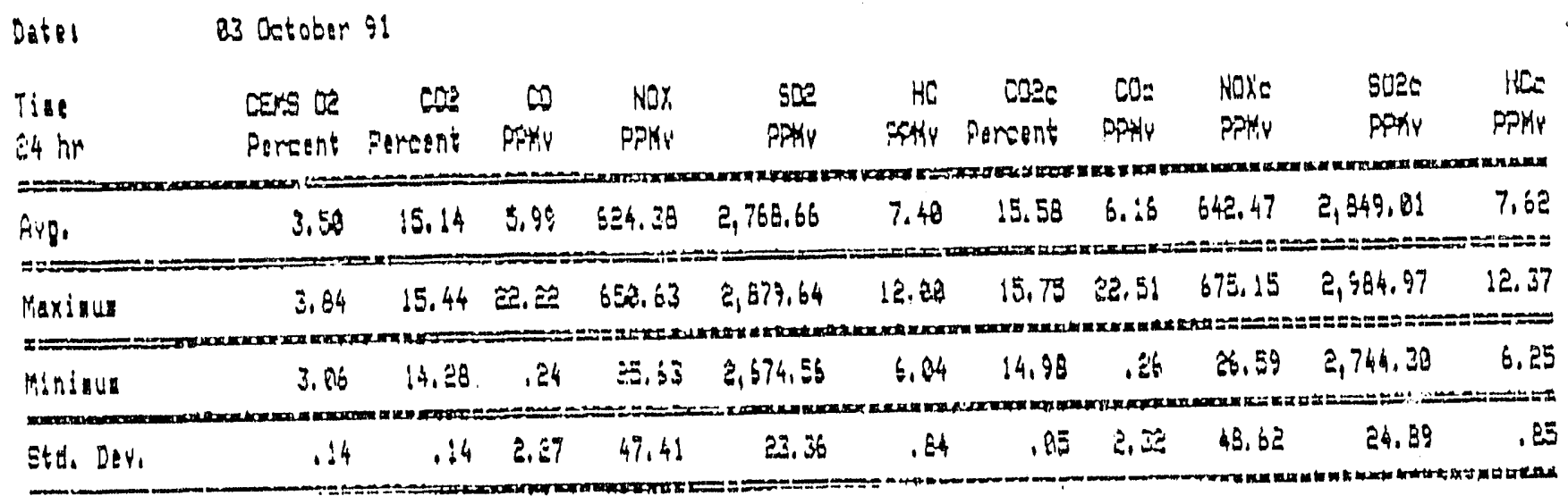

Energy L Environnental Rescareh

Conidnuous Eajasions Yoristering

Thirty Second Arerage Data

Datel az Detuchat
Tes: No.

Plante Lakegioe Init No.?

Loads 25 ind

Plant ce levedi Norsel

\begin{tabular}{|c|c|c|c|c|c|c|c|c|c|c|c|}
\hline Tlap & CENG [2 & $\cos$ & DD & NOK & 302 & sin & $\cos \bar{C}$ & Can. & $110 \times 6$ & SQEF & $\mathrm{HCO}$ \\
\hline$h r$ & Paicentil & Fircast & Pryy & PPAN & FPAV & PFip & Fereent & PQHYY & PFMY & Primy & PPHAY \\
\hline \multicolumn{12}{|c|}{ 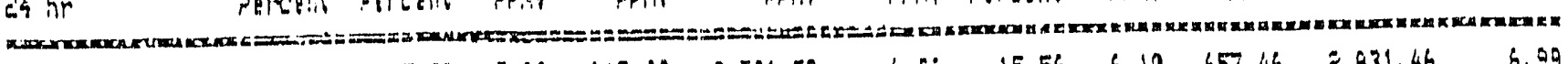 } \\
\hline YQ. & 3.31 & 15. 20 & 5.99 & 545.39 & $2,751,39$ & $b_{1} 00$ & 15.55 & 6.18 & 657.46 & $E_{1} 63 ! .46$ & 6.99 \\
\hline $1 \times: N d d$ & & & $0=2$ & is & & 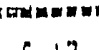 & Len & ne numurnom & $x \in \mathbb{X}$ & $=0$ & in \\
\hline \multicolumn{12}{|c|}{ 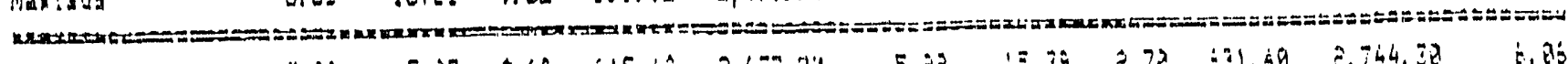 } \\
\hline 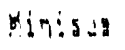 & $\vdots, 1 \vdots$ & $: 5.25$ & $\varepsilon_{1} \dot{s} \hat{8}$ & $315.4 \hat{\theta}$ & $2,67 \%, 10$ & $5.9 ?$ & 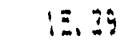 & 2.72 & $\$ 2 ! .4 \theta$ & $2,744,32$ & $\therefore, B$ \\
\hline
\end{tabular}




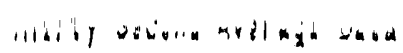

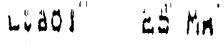

Daber $\quad 84$ Datoters $\$ 1$

Plant de Leveld Low

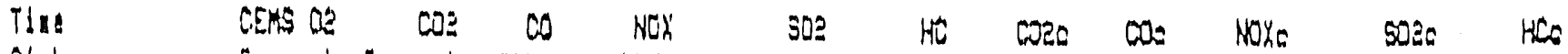

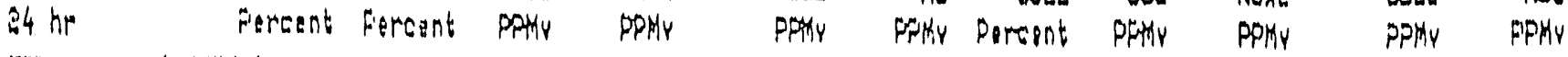

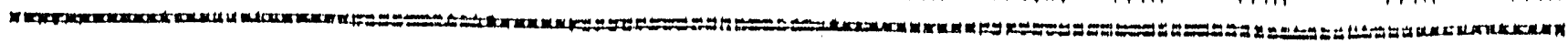

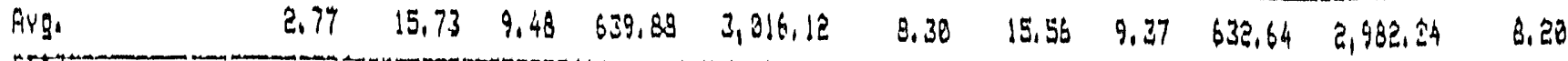

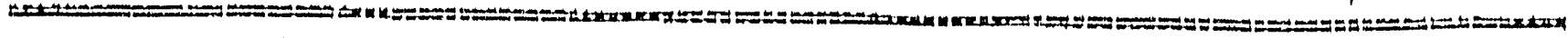

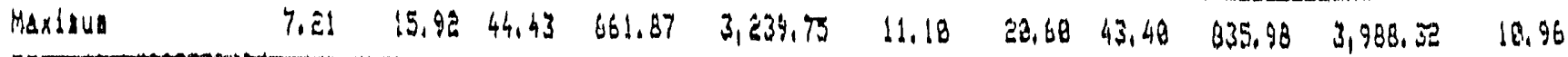

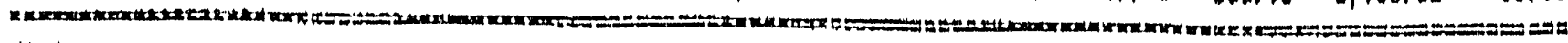

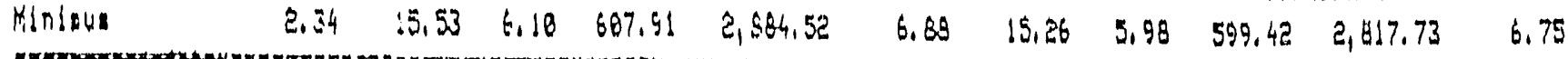

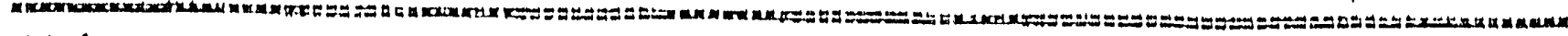

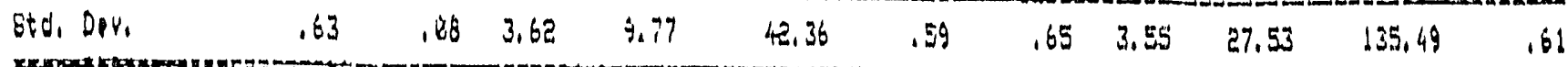

Energy \& Enviraribentad Rasearacil Continuous Ells siors Monitoring Thirty Brovid fyerage Dit:

Dater Q4 Derober it
Test Nio. $\quad$ it

P!antl Lakes!de Un! Na. 7

Loads 就

Plant De LuYli Low

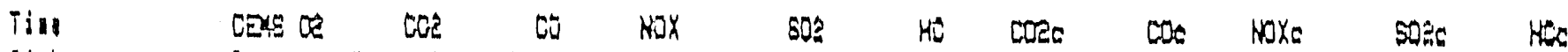

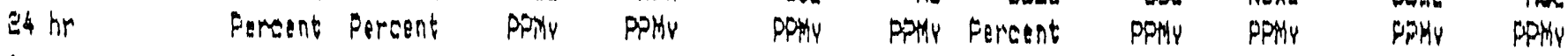

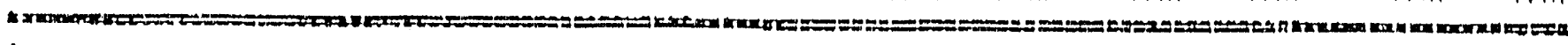

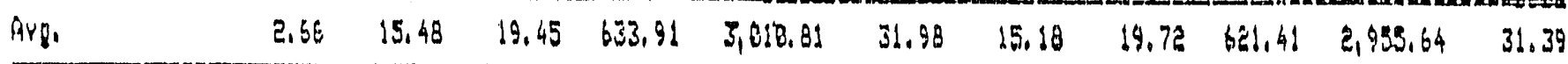
.

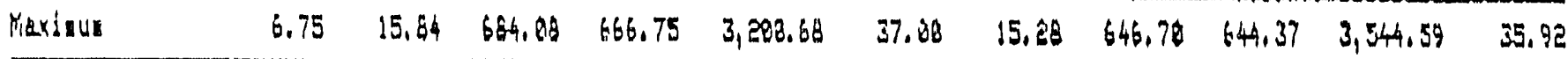

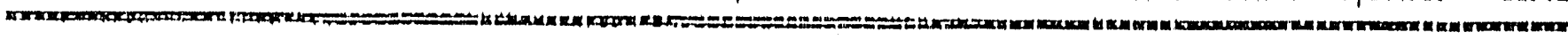

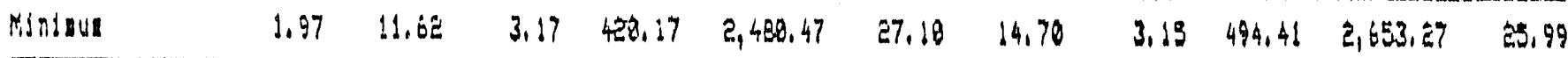

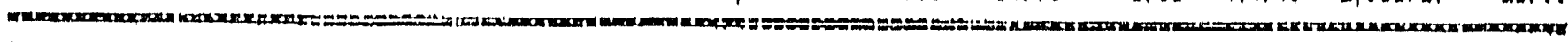

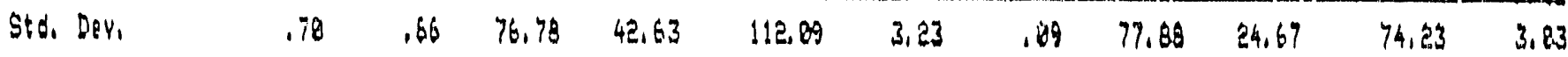

Energy L Environarnital Resegron Continuaus Ealssions Monitoring

Thirty Secoid Ayorzoo Dita

Datel

07 Datober of
Tost No.

Planti Lakesdo Lhit No.Y

Load 19.5 HA

Plant oz Luydi Noraad

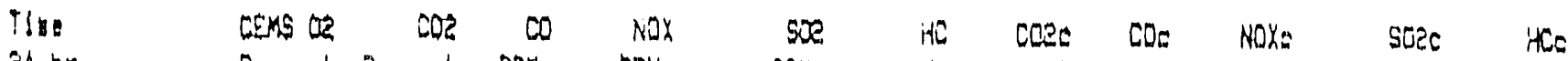

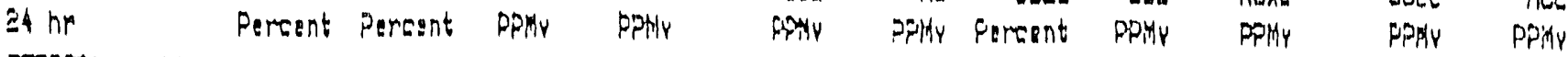
= Av8. $\quad 3.57 \quad 15.89 \quad 3.12 \quad 613.78 \quad 2,748.92 \quad 16.58 \quad 15.59 \quad 3.22 \quad 634.18 \quad 2,796.62 \quad 17.85$

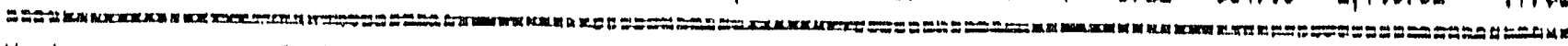

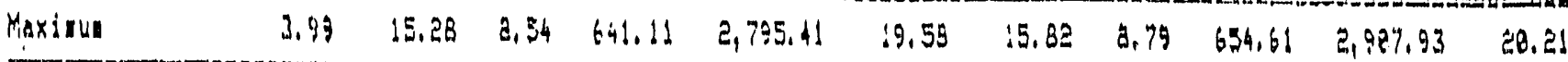
m

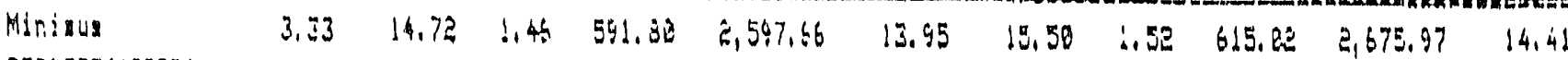


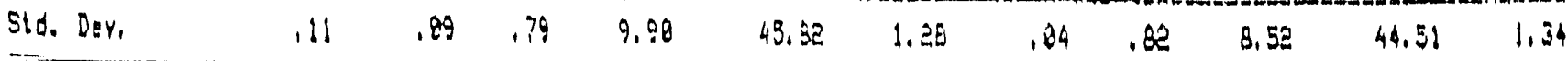


Energy \& Enyiromantsl Respacth Continuous Faissions Monitor!ng Thirty Second Averano Data

Datal of Detobar or
Tert No,

Plantil Lakeside Unit No.?

Loudi $19.5 \mathrm{Kk}$

Plant de levali Noraal

\begin{tabular}{|c|c|c|c|c|c|c|c|c|c|c|c|}
\hline 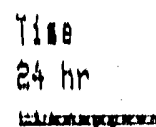 & $\begin{array}{l}\text { Cens de } \\
\text { Parcent }\end{array}$ & $\begin{array}{r}\text { was } \\
\text { Piprount }\end{array}$ & $\begin{array}{l}\text { CD } \\
\text { CHSA }\end{array}$ & $\begin{array}{l}\text { NoX } \\
\text { NPHY }\end{array}$ & 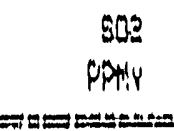 & WC & $\begin{array}{l}\text { Coeac } \\
\text { Parcant }\end{array}$ & POMA & $\begin{array}{l}\text { NOXE } \\
\text { PPMYY }\end{array}$ & $\begin{array}{l}\text { SLPeg } \\
\text { PPMYY }\end{array}$ & $\begin{array}{r}\text { Hëe } \\
\text { Pristy }\end{array}$ \\
\hline$\theta_{1}$ & 3,60 & 1908 & 3.5 & 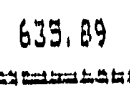 & 2,754, 欧 & $\begin{array}{l}14,56 \\
=9: 5=2\end{array}$ & $\begin{aligned} 13,59 \\
0\end{aligned}$ & $\begin{array}{l}3,44 \\
1,4=x=8\end{array}$ & 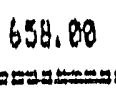 & $2_{1,149,90}$ & 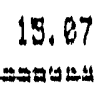 \\
\hline nus & 4,03 & 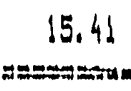 & $\{5,6\}$ & $65 e_{1}, 03$ & 2, 2898,18 & 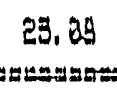 & 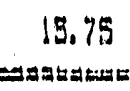 & 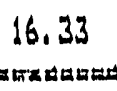 & $\begin{array}{r}674.75 \\
\end{array}$ & ${ }_{2,961,17}$ & 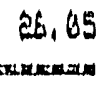 \\
\hline & 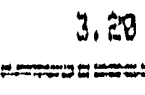 & 14.73 & 1,22 & $\begin{array}{l}618.63 \\
=8 x=0\end{array}$ & $\begin{array}{l}2,648,93 \\
=-1\end{array}$ & 12,44 & 15.38 & $=1, \hat{A}$ & 642.23 & $2,729.41$ & $\begin{array}{l}11,83 \\
=\pi \times x=0 \pi\end{array}$ \\
\hline Der. & .11 & .180 & 1. & 6.78 & 31.67 & 1,50 & .84 & 1.40 & 6.66 & 29,09 & 4.55 \\
\hline
\end{tabular}

Eneroy S Enriranoenta! Roseupah

Continuous Ealcrisns Montsuring

Thlrty Spcond Ayerage Data

Date: 07 Catober 91
Tess No.

15

Plantl Lakaside Unit No.7

Lo201 19.5 Mh

Plant de Lavoli Narsad

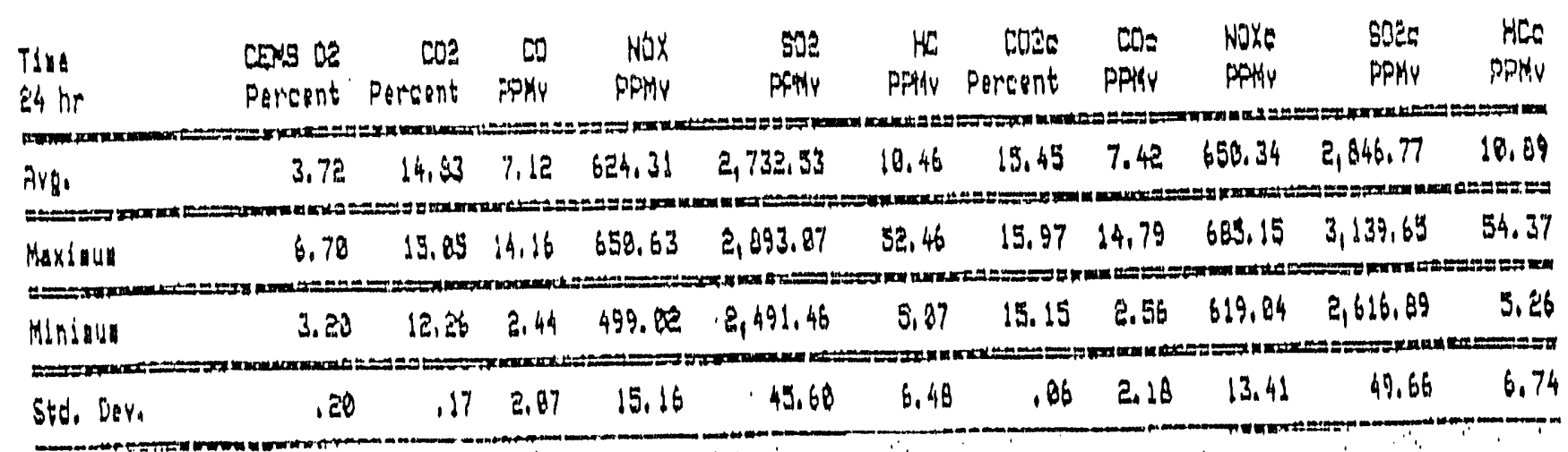

Enoroy I Environzental Ressureh Conthuous Erlisicts Monacoring Thirty Second Aypragio Data

Dater Detoher 91
Test Ho. 16

Planti Lakeside Undt No.?

Loads 19.5 W

plant de Leveld Low

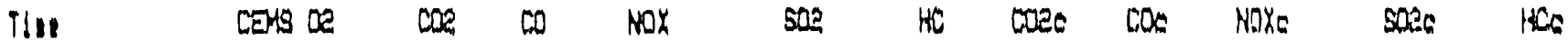

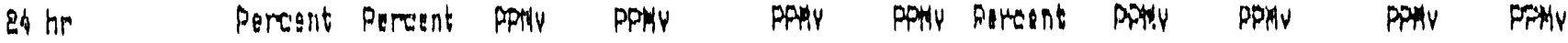
mon-

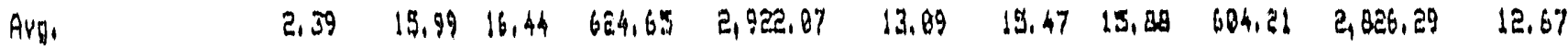

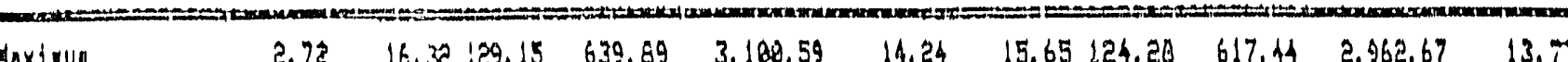

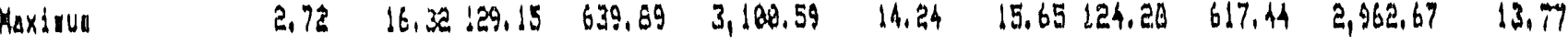

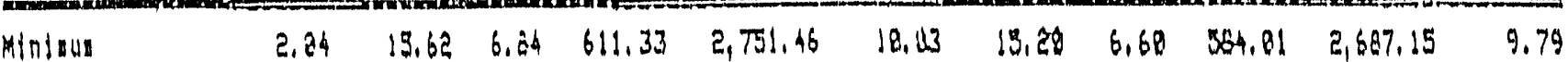
.

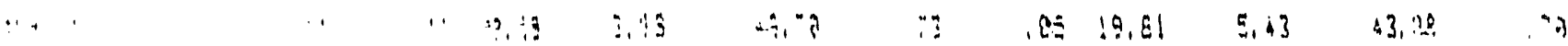


Energy L Enviromantal Resparah

Continuous Eubssons Manthor!ng

Thirty Second Aygrage Date
Tost Ho, 17

Planti Lakesida Unit No.?

Load1 $19.5 \mathrm{~mW}$

plant oe Leprli Low

\section{Dato1 actobar 91}

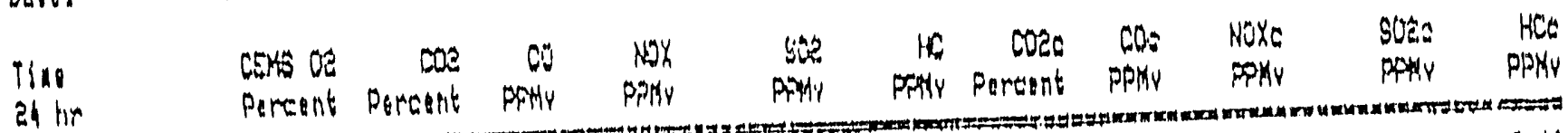

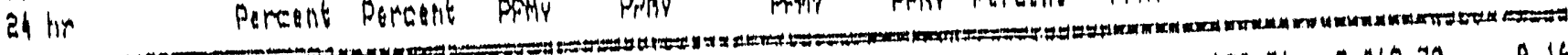

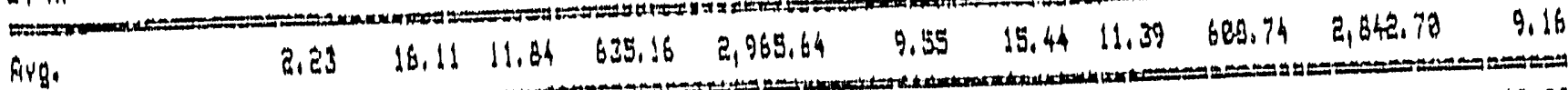

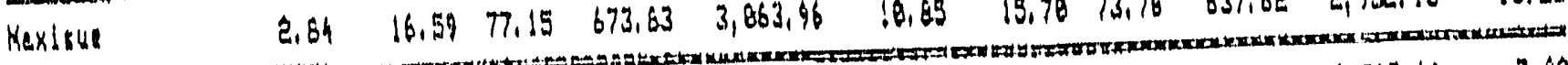

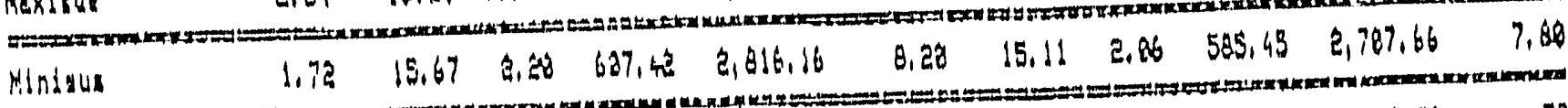

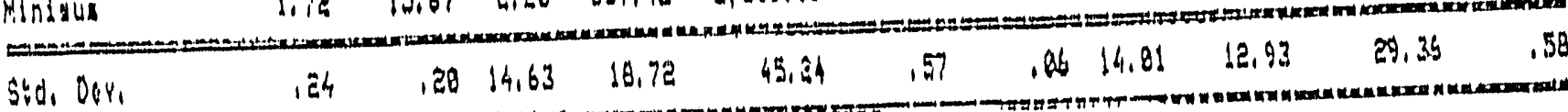

Energy t Enviromentsd Racourat

Continuevs Ealsalons Monitarlng

Thirby Second Averago Dat:
Thit No, 18

Plantit Lekeside Unst No.7

Load1 19.5 M

Plant ae Levell how

\section{Datas astobar 91}

\begin{tabular}{|c|c|c|c|c|c|c|c|c|c|c|c|}
\hline ante & 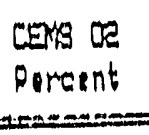 & Siment & $\begin{array}{c}C D \\
P P N N_{4}\end{array}$ & 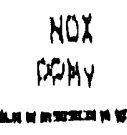 & 蓶 & $\begin{array}{r}X_{1} \\
P Q A 4 \\
\end{array}$ & $\begin{array}{l}\text { Coper } \\
\text { Perepht }\end{array}$ & $\begin{array}{c}C O C \\
\text { PrAty }\end{array}$ & $\begin{array}{l}\text { NOXG } \\
\text { PPXY }\end{array}$ & 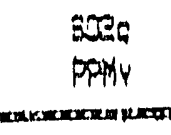 & $\begin{array}{l}\text { HCO } \\
\text { PPMY } \\
\end{array}$ \\
\hline & 1,89 & 18.37 & $64,3 !$ & 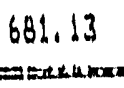 & $3,843,83$ & 7,90 & 15.42 & 62.14 & 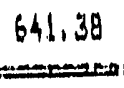 & $2,865,41$ & 7.44 \\
\hline oxiav" & 3.41 & 16.8 & 636.67 & $7 \xi h_{1}, 83$ & $3,132,3$ & 18,72 & 16.80 & $\begin{array}{c}591,21 \\
=\end{array}$ & $\begin{array}{l}698,76 \\
=2=0\end{array}$ & $\begin{array}{l}3,127,38 \\
0\end{array}$ & 18.18 \\
\hline 3U. & 1,48 & 1.5 .94 & .73 & $64 \%$ 证 & $2,977.29$ & 6.28 & 15,28 & $\begin{array}{l}.78 \\
x=2 x=0\end{array}$ & 600,43 & $0,817,08$ & 5.67 \\
\hline & .19 & .14 & 119.68 & 24,23 & 28,45 & .97 & .11 & 111,92 & 23.27 & 31,81 & 92 \\
\hline
\end{tabular}

Energy 6 Enyironatntal Rastarch

Continuous Elissions Moriboring

Thlrty Sacond Averaga Data
Test Nipo 19

Plants: Lakeside Unit No.y

Load: 35 W

Plant De Leveds Low

Datis as acrobar 91

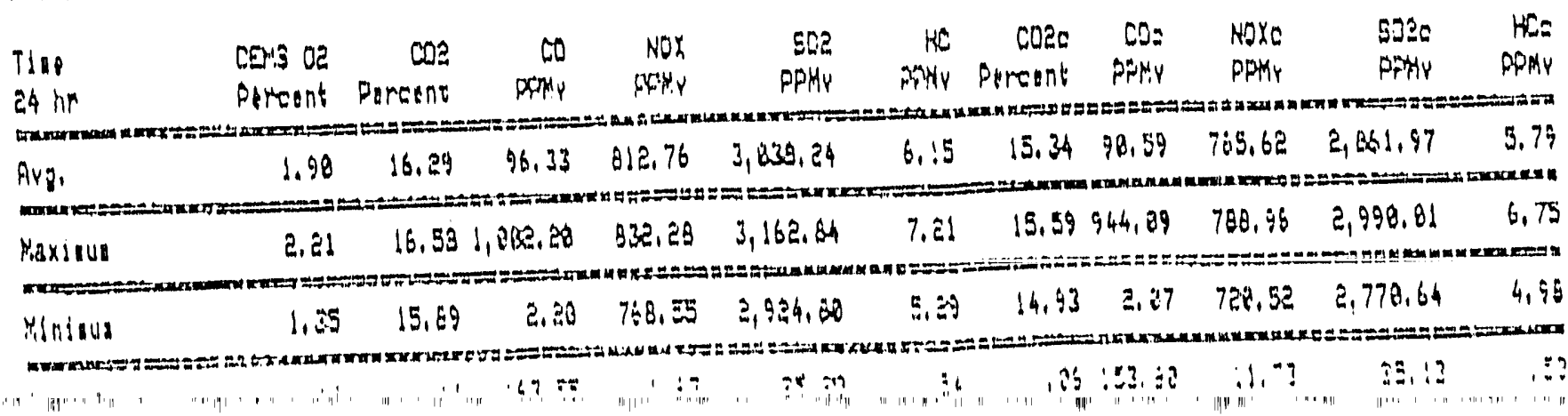


Energy I Eny!ronuenta! Rescaret

Conibinuous Enlssions Kondtoring

Thirty Second Akrrape Dato

\section{Dete: 19 Detober 91}

\begin{tabular}{|c|c|c|c|c|c|c|c|c|c|c|c|}
\hline $\begin{array}{l}\text { Tine } \\
\text { 2h lir }\end{array}$ & $\begin{array}{l}\text { Dars ne } \\
\text { Perant }\end{array}$ & $\begin{array}{r}\text { cone } \\
\text { Peretint }\end{array}$ & $\infty$ & $\begin{array}{l}\text { 10DX } \\
\text { PPNYY }\end{array}$ & 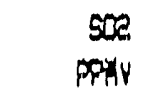 & $\underset{x}{W}$ & perent & $\underset{p a n y}{a t e}$ & $\begin{array}{l}\text { Moxs } \\
\text { PANHY }\end{array}$ & Does & $\begin{array}{l}\text { HCO } \\
\text { PCANY }\end{array}$ \\
\hline H. & 3. 36 & 15.23 & 6.44 & 645.19 & $2,686.24$ & 4.98 & 15.4 & 6.57 & 659,49 & $2,741.69$ & 5.89 \\
\hline xallou & 3.97 & 15.39 & 65.92 & 678.98 & $2,883.96$ & 6.24 & 15.69 & 66.96 & 682.12 & $2,863,48$ & 6.33 \\
\hline ntaun & 2.97 & 14,69 & 2.4 & $623, \hat{B}$ & $2,318,99$ & 3.78 & 14,94 & 2.47 & 648,0 & $2,558,68$ & 3.91 \\
\hline$d_{1}$ Der, & .15 & .13 & 8.87 & 7,33 & 61,0 & .68 & 186 & 9.22 & 6,24 & 66.56 & .69 \\
\hline
\end{tabular}

Test No, 30

Planti Lakesido Unát No.7

Loadd 25.5 w

Plant Ce Leruls Horad 

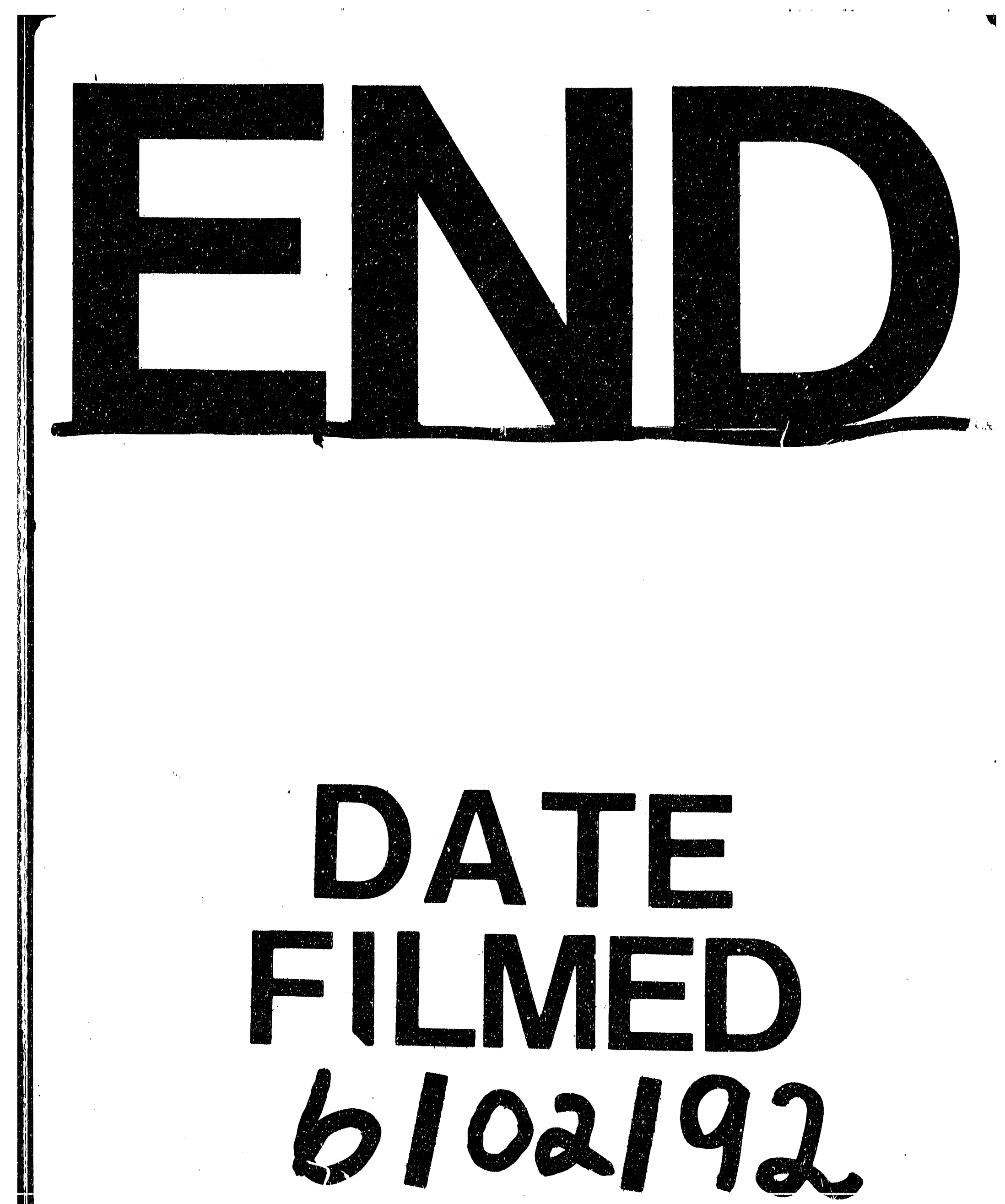